\title{
Conflitos socioambientais em torno do Aterro Sanitário Metropolitano Oeste de Caucaia, Ceará, Brasil
}

\section{Maria Laudecy Ferreira de Carvalho1,*, Joel Silva dos Santos $^{1}$, Luan Gomes dos Santos de Oliveira ${ }^{2}$ e Ana Bárbara de Araújo Nunes ${ }^{3}$}

\author{
${ }^{1}$ Universidade Federal da Paraíba. Programa de Pós-Graduação em \\ Desenvolvimento e Meio Ambiente (PRODEMA). Campus I. João Pessoa-PB, Brasil \\ (CEP 58051-900). *E-mail: laudecyferreira@gmail.com. \\ ${ }^{2}$ Universidade Federal de Campina Grande. Centro de Ciências Jurídicas e Sociais. \\ Sousa-PB, Brasil (CEP 58800-240). \\ ${ }^{3}$ Universidade Federal do Ceará. Departamento de Engenharia Hidráulica e \\ Ambiental. Campus do Pici. Bloco 713. Fortaleza-CE, Brasil (CEP 60440-970).
}

Resumo. 0 objetivo deste artigo foi constatar os conflitos socioambientais causados pelas ações da gestão dos resíduos com a instalação e a operacionalização do Aterro Sanitário Metropolitano Oeste de Caucaia (ASMOC) e da Usina GNR Fortaleza Valorização de Biogás Ltda, localizados no Município de Caucaia Região Metropolitana de Fortaleza, Nordeste do Brasil. A pesquisa parte do entendimento de que o aterro e a usina têm gerado externalidades ambientais, e consequentemente, conflitos socioambientais. A metodologia utilizada para a compreensão e caracterização dos conflitos socioambientais na área de estudo, utilizou-se do arcabouço teórico fundamentado por diversos autores da Ecologia Política. Foram realizadas entrevistas e aplicação de questionários semiestruturados com atores sociais da gestão e do entorno da usina de biogás e do aterro sanitário para melhor compreensão do surgimento dos conflitos socioambientais tomando-se como base a Ecologia Política. Assim como, a investigação documental, levantamento bibliográfico, visita de campo e registro fotográfico. Os resultados obtidos sinalizaram vários conflitos socioambientais, a exemplo de luta urbana por ar e água limpos, espaços verdes, direitos dos ciclistas e pedestres, a defesa dos rios, a degradação dos solos, a luta dos trabalhadores pela saúde e segurança ocupacional, o racismo ambiental, o ecologismo dos pobres, a população ter direito ao acesso ao biometano produzido pela usina GNR, dentre outros.

Palavras-chave: Ecologia Política; Conflitos socioambientais; Aterro sanitário; Usina de biogás; Caucaia; Ceará; Brasil.
Recebido

$28 / 09 / 2021$

Aceito

$24 / 12 / 2021$

Publicado

$31 / 12 / 2021$

Acesso aberto

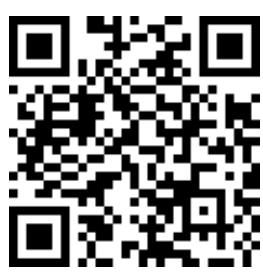

ORCID

(D) 0000-0002-4868-8997

Maria Laudecy

Ferreira de Carvalho

(D) 0000-0002-8068-630X Joel Silva dos Santos

ISSN 2359-1412/RBGAS-2021-0122/2021/8/20/27/1707

Rev. Bras. Gest. Amb. Sustent.

http://revista.ecogestaobrasil.net 
Abstract. Social and environmental conflicts around the Metropolitan Sanitary Landfill West of Caucaia, Ceará, Brazil. The objective of this article was to verify the socio-environmental conflicts caused by the actions of waste management with the installation and operation of the Metropolitan Sanitary Landfill West of Caucaia (ASMOC) and the GNR Power Plant Valorização de Biogás Ltda, located in the Municipality of Caucaia Metropolitan Region of Fortaleza, Northeast of Brazil. The research is based on the understanding that the landfill and the plant have generated environmental externalities, and consequently, social and environmental conflicts. The methodology used to understand and characterize the socioenvironmental conflicts in the study area used the theoretical framework founded by several authors in Political Ecology. Interviews and application of semi-structured questionnaires were carried out with social actors in the management and surroundings of the biogas plant and the landfill for a better understanding of the emergence of socio-environmental conflicts, based on Political Ecology. As well as documental investigation, bibliographic survey, field visit and photographic record. The results obtained signaled several socio-environmental conflicts, such as the urban struggle for clean air and water, green spaces, rights of cyclists and pedestrians, the defense of rivers, soil degradation, the struggle of workers for occupational health and safety, racism environment, the ecologism of the poor, the population having the right to access the biomethane produced by the GNR plant, among others.

Keywords: Political Ecology; Social and environmental conflicts; Landfill; Biogas plant; Caucaia; Ceará; Brasil.
D) 0000-0001-6642-0006

Luan Gomes dos

Santos de Oliveira

(ㄷ) 0000-0001-6059-8540

Ana Bárbara de Araújo

Nunes

\section{Introdução}

Para compreender a relação entre o uso dos recursos naturais e os conflitos socioambientais, é imprescindível o uso da Ecologia Política como chave de leitura e interpretação dos fatos. A partir desse olhar crítico é possível evidenciar a crise ambiental com foco nos conflitos socioambientais, se fortalecendo por meio da crescente articulação entre os movimentos ambientalistas e sociais a partir dos anos 1980, com práticas e saberes teóricos e políticos com base nos conflitos ecológicos distributivos (Porto e Martinez-Alier, 2007).

Nesse sentido, para iniciar o diálogo interdisciplinar, a Ecologia Política partiu do espaço rural destacando as situações que envolvem os recursos naturais e a sociedade com ênfase nas questões relacionadas ao solo e a agricultura dos países em desenvolvimento do eixo sul do globo e uma visão direcionada ao urbano-industrial dos países do eixo norte do globo. Nessa perspectiva interdisciplinar, a Ecologia Política procura por conceitos e métodos em outros componentes curriculares, a exemplo da história, medicina, antropologia, dentre outros, com o objetivo de compreender e identificar como funcionam e se inter-relacionam os atores sociais em seus distintos níveis no processo de luta sociopolítica e ambiental (Zimmerer e Basset, 2003; Little, 2006; Araújo e Gomes, 2017). 
Segundo Scotto (1997), para saber sobre os conflitos socioambientais se faz necessário identificar e analisar os atores sociais que fazem parte dos referidos conflitos, haja vista ser base para conhecer os interesses e interações nos aspectos coletivos e privados de cada um desses atores. Esses conflitos acontecem de forma implícita ou explícita devido à apropriação de espaços ou recursos coletivos por diferentes atores sociais para atender interesses pessoais.

Nesse contexto, pretende-se neste artigo discorrer sobre os conflitos socioambientais decorrentes da instalação e operacionalização do Aterro Sanitário Metropolitano Oeste de Caucaia (ASMOC) e da Usina de Biogás Gás Natural Renovável Fortaleza Valorização de Biogás Ltda (GNR), localizados no Município de Caucaia Região Metropolitana de Fortaleza, Nordeste do Brasil. Para isso, teve-se uma escuta atenta com os atores sociais do ASMOC, da usina GNR e a população do entorno.

\section{Metodologia}

Para desenvolver esta pesquisa na busca por identificar os conflitos socioambientais provenientes do processo de instalação e operacionalização do Aterro Sanitário ASMOC e da Usina de Biogás GNR Fortaleza e a população do entorno, classificou-se o trabalho quanto sua abordagem, natureza, objetivos e procedimentos metodológicos.

Quanto à abordagem, optou-se pela abordagem qualitativa, devido à necessidade de se compreender a relação entre os atores sociais, os empreendimentos e o uso dos recursos naturais sob a ótica de Ecologia Política, pois se entende que os impactos e os conflitos socioambientais também são observados na subjetividade e nas suas nuances, que muitas vezes não são quantificáveis.

Quanto à natureza, optou-se por uma pesquisa de cunho teórico e aplicada que através da chave de leitura da Ecologia Política foi possível compreender a complexidade dos problemas socioambientais gerados pela instalação e operacionalização do Aterro ASMOC e da Usina de Biogás e sua população local na Região Metropolitana de Fortaleza, Estado do Ceará, Nordeste do Brasil.

Quanto aos objetivos, utilizou-se de pesquisa descritiva, exploratória e explicativa. Partiu-se da descrição geográfica dos empreendimentos e sua relação com a população do entorno. Enquanto que a realização da pesquisa exploratória utilizou-se da ferramenta dos questionários para perceber melhor as subjetividades dos atores sociais envolvidos nesta pesquisa. Por fim, buscou-se a interpretação dos fatos sob a ótica da Ecologia Política.

Existem vários tipos de procedimentos metodológicos para a realização de uma pesquisa científica. Nesta pesquisa, diante dos seus objetivos, problemática e área de estudo, optou-se pelos seguintes procedimentos: Pesquisa Bibliográfica, Pesquisa Documental, Pesquisa de Campo, Levantamento de dados e uso da técnica "Bola de Neve".

Para a realização da pesquisa, inicialmente foi realizado o levantamento bibliográfico e documental a respeito da temática em questão e da área de estudo. Para esta pesquisa foram analisados os seguintes documentos, Estudo de Impacto Ambiental (EIA) e respectivo Relatório de Impacto Ambiental (RIMA), Licença Prévia (LP), Licença de Instalação (LI), Licença de Operação (LO), Plano de Gerenciamento de Resíduos Sólidos, dentre outros.

Posteriormente, foi realizado o reconhecimento da área de estudo através de visita de campo com registro fotográfico e entrevista com os atores sociais da pesquisa.

Para a escolha dos atores sociais que fizeram parte das entrevistas e questionários semiestruturados, deste estudo, utilizou-se da técnica "Bola de Neve" (Biernack e Waldorf, 1981), de acordo com o citado na metodologia desta pesquisa. Foram realizadas 10 entrevistas e 14 questionários com os envolvidos com a pesquisa, a exemplo do senhor Lucas Sousa que indicou a senhora Carolina Sales e assim consecutivamente. 
A obtenção das informações sobre a usina de biogás GNR, foram elaborados questionários semiestruturados e entrevistas em duas etapas, haja vista no decorrer da pesquisa haver necessidade de se aprofundar nas respostas obtidas junto à diretoria e analista de operação. No que se refere a obtenção de informações junto ao aterro sanitário do ASMOC, junto à gerência e funcionários foram elaborados questionários, assim como, foi realizada entrevista com a população do entorno.

Durante o período da pandemia da COVID-19, as atividades relacionadas à visita de campo foram suspensas por 6 meses, retomando somente a partir de maio de 2021.

\section{Resultados e discussão}

\section{Identificação e classificação dos tipos de conflitos socioambientais e econômicos do aterro sanitário ASMOC e da Usina de biogás GNR}

Os conflitos socioambientais são caracterizados por três tipos, os conflitos em torno dos impactos socioambientais, a exemplo da instalação de aterro sanitário e de usina de biogás que podem contaminar água, ar e solo, degradar a vegetação, situações geradas pela ação humana; os conflitos acerca da disputa pelo controle sobre os recursos naturais, a exemplo do desmatamento para implantação de loteamento, de modo a favorecer quem é mais rico e explorar os mais pobres; os conflitos em torno de valores culturais edo modo de vida, ou seja, por envolver o uso da natureza a desapropriação de atores sociais que fortalecem vínculos familiares (Little, 2002; Muniz, 2009).

Vários são os tipos de conflitos socioambientais existentes em todo o mundo. Para conhecer mais ainda sobre os tipos de conflitos ambientais distributivos e/ou conflitos socioambientais, Martinez-Alier (2007) traz um panorama distribuído em vinte e quatro tipos de conflitos, revelando o aumento das tensões pelo acesso aos recursos naturais e a relação entre o crescimento econômico e uso dos referidos recursos, como citados a seguir:

1) 0 racismo ambiental; 2) As lutas tóxicas; 3) 0 imperialismo tóxico; 4) 0 intercâmbio ecologicamente desigual; 5) Conflitos judiciais contra empresas transnacionais; 6) A dívida ecológica; 7) A biopirataria; 8) A degradação dos solos; 9) Plantações não são florestas; 10) Manguezais versus carcinicultura; 11) A defesa dos rios; 12) Os conflitos mineiros; 13) A contaminação transfronteiriça; 14) Os direitos locais e nacionais de pesca; 15) Os direitos igualitários aos sumidouros e aos depósitos de carbono; 16) 0 espaço ambiental; 17) Os invasores ecológicos versus as pessoas dos ecossistemas; 18) As lutas dos trabalhadores pela saúde e segurança ocupacional; 19) A luta urbana por ar e água limpos, espaços verdes, direitos dos ciclistas e pedestres; 20) A segurança dos consumidores e dos cidadãos; 21) Conflitos relacionados com o transporte; 22) 0 ecologismo indígena; 23) 0 ecofeminismo social, o feminismo ambiental; 24) 0 ecologismo dos pobres (Martinez-Alier, 2007; Bordalo, 2019, p. 89).

Dessa forma, compreende-se que os problemas socioambientais são formas de conflitos sociais entre interesses individuais e coletivos, envolvendo a relação entre sociedade e natureza. E é durante o processo de confrontação do jogo de interesses antagônicos que se configuram os conflitos socioambientais. "Nada pode ser intelectualmente um problema, se não tiver sido, em primeiro lugar, um problema na vida prática" (Minayo, 2001, p. 17).

De acordo com Scotto (1997), Little (2002), Leff (2006), Martinez-Alier (2007) e Porto e Martinez-Alier (2007), foi possível identificar e classificar os conflitos socioambientais existentes na pesquisa deste estudo como mostra a Tabela 1. Dos 24 tipos de conflitos socioambientais citados por Martinez-Alier (2007), sete fazem parte da realidade da área deste estudo como os citados na Tabela 1, os conflitos relacionados com 
o transporte; a luta urbana por ar e água limpos, espaços verdes, direitos dos ciclistas e pedestres; a defesa dos rios; a degradação dos solos; as lutas dos trabalhadores pela saúde e segurança ocupacional; racismo ambiental e o ecologismo dos pobres.

Tabela 1. Identificação e classificação dos tipos de conflitos socioambientais e econômicos do aterro sanitário ASMOC e da Usina de biogás GNR.

\begin{tabular}{|c|c|}
\hline $\begin{array}{l}\text { Identificação } \quad \text { dos } \\
\text { conflitos socioambientais }\end{array}$ & Classificação dos conflitos socioambientais \\
\hline $\begin{array}{l}\text { - Conflitos relacionados } \\
\text { com o transporte. }\end{array}$ & $\begin{array}{l}\text { Ambiental: Físico (solo - degradação do solo por meio do transporte } \\
\text { dos veículos pesados). }\end{array}$ \\
\hline $\begin{array}{l}\text { - A luta urbana por ar e } \\
\text { água limpos, espaços } \\
\text { verdes, direitos dos } \\
\text { ciclistas e pedestres. }\end{array}$ & $\begin{array}{l}\text { Ambiental: Físico (contaminação do ar, água, solo com a } \\
\text { decomposição dos resíduos sólidos urbanos - RSU). } \\
\text { Ambiental: Biótico (derrubada da vegetação para instalação dos } \\
\text { empreendimentos). } \\
\text { Social: Antrópico (ciclistas e pedestres não têm espaços apropriados } \\
\text { para a sua circulação nas vias do entorno das residências, do aterro } \\
\text { sanitário e da usina de biogás. Ainda, que circulam por ruas sem } \\
\text { pavimentação ou em espaços sendo divididos com os caminhões e } \\
\text { nos períodos chuvosos ficam intransitáveis). }\end{array}$ \\
\hline - A defesa dos rios. & $\begin{array}{l}\text { Ambiental: Físico (água do Riacho Garoto e da Lagoa João Batista } \\
\text { estão poluídos pela decomposição dos resíduos sólidos urbanos, ou } \\
\text { seja, impróprios para o uso humano). }\end{array}$ \\
\hline - A degradação dos solos. & $\begin{array}{l}\text { Ambiental:Físico (com o desmatamento para instalação dos } \\
\text { equipamentos em discussão, com a poluição provocada pela } \\
\text { exposição dos resíduos sólidos urbanos, circulação de veículos } \\
\text { pesados no transporte dos resíduos sólidos urbanos - RSU). }\end{array}$ \\
\hline $\begin{array}{l}\text { As lutas dos } \\
\text { trabalhadores pela saúde e } \\
\text { segurança ocupacional. }\end{array}$ & $\begin{array}{l}\text { Ambiental: Físico (com a contaminação da água, tem-se o relato de } \\
\text { moradores com doenças de pele, doença respiratória, poluição } \\
\text { sonora com o funcionamento da usina e poluição do ar com os gases } \\
\text { de feito estufa e o mal cheiro causado pela decomposição dos RSU } \\
\text { por meio do chorume). } \\
\text { Social: Para a realização do trabalho junto aos dois equipamentos } \\
\text { mesmo com uso de máscara e protetor auricular, o mal cheiro pela } \\
\text { decomposição dos RSU é inevitável, assim como com a poluição } \\
\text { sonora na geração do biogás, que mesmo com protetor auricular o } \\
\text { barulho é inevitável. }\end{array}$ \\
\hline - Racismo ambiental. & $\begin{array}{l}\text { Social: Antrópico (várias famílias vivendo às margens do aterro } \\
\text { sanitário ASMOC, em situação de invisibilidade econômica, de saúde } \\
\text { e social). A dispersão territorial das casas da comunidade favorece à } \\
\text { invisibilidade dessa população do entorno. O que favorece a } \\
\text { intensificação do processo de segregação socioespacial, próprio da } \\
\text { lógica que privatiza a cidade. }\end{array}$ \\
\hline - O Ecologismo dos pobres. & $\begin{array}{l}\text { Social: Antrópico (população do entorno na busca da fonte e condição } \\
\text { para o sustento). }\end{array}$ \\
\hline
\end{tabular}

Fonte: Adaptado de Martinez-Alier (2007).

Diante das discussões sobre os conflitos socioambientais existentes entre os atores sociais foi percebido que é insuficiente a participação dos governos locais em criar espaços de articulação e/ou interação com a população do entorno, no sentido de dar visibilidade aos diversos interesses em jogo. Assim sendo, torna-se cada vez mais distante a efetivação 
por justiça ambiental diante do uso dos recursos naturais coletivos, tendo em vista a gestão dos interesses dominantes. Essa falta de interação na relação é percebível quando da realidade da moradora do entorno do aterro, senhora Carolina Sales que mesmo sendo a proprietária da Lagoa João Batista que fica no quintal da sua casa, onde supria as necessidades básicas da família a exemplo de beber, lavar roupas, cozinhar, tomar banho, teve que isolar o uso por estar imprópria, a água que antes era doce, passou a ser salobra, ou seja, possui uma quantidade de sal elevada (cloretos).

A Lagoa João Batista que abastecia a residência da moradora Carolina Sales e da vizinhança do entorno do aterro sanitário ASMOC, apesar de ser uma lagoa perene, sua água tornou-se imprópria para uso doméstico e animal de qualquer natureza, tendo em vista causar problemas de saúde para a população do entorno e apresentar-se insalubre para o consumo. A moradora informa que até mesmo as cacimbas tiveram que ser soterradas por não ter condições de uso. Antes da instalação do aterro sanitário ASMOC, tanto a lagoa quanto as cacimbas, tinham uso geral para a população do entorno, embora com a existência do aterro tudo mudou, inclusive agora ter que pagar água da Companhia de Água e Esgoto do Ceará (CAGECE) que abastece as residências. A moradora informa ainda que a vida da sua família tornou-se mais difícil em todos os aspectos por ter a saúde comprometida e a vida econômica cada vez insuficiente "Olhar essa lagoa com tanta água e não ter serventia dá uma dor muito grande em saber que tanto nos serviu por mais de 30 anos. Hoje não serve mais". Disse Dona Carolina Sales: "Aqui em casa todos nós sentimos muita dor de cabeça, agitação, fadiga na visão, coceira na pele, mal-estar, diarreia, enjoo. Às vezes penso que é por causa desse aterro sanitário no pé da porta da minha casa". A residência da senhora Carolina Sales fica a menos de 3 metros do portão de entrada do aterro sanitário ASMOC.

Nesse sentido, ao recorrer a estudos sobre a fala da senhora Carolina Sales, viu-se que o Departamento de Medicina da Universidade de São Paulo, no ano de 2010, havia publicado um artigo sobre os "Riscos à saúde em áreas próximas a aterros de resíduos sólidos urbanos", com o objetivo de avaliar a associação entre residência próxima a aterros de resíduos sólidos e a ocorrência de câncer e malformações congênitas nessas populações vizinhas. A pesquisa exploratória e aplicada aconteceu no período entre 1998 a 2002, no Município de São Paulo, com raios de $2 \mathrm{~km}$ em torno de 15 aterros. Os resultados apontaram para a ocorrência de "351 óbitos por câncer de fígado, 160 de bexiga e 224 por leucemia em adultos, 25 óbitos por leucemia entre crianças e 299 por malformação congênita nas áreas próximas aos aterros” (Gouveia e Prado, 2010, p. 859).

Para Gouveia e Prado (2010), "[...] estudos têm indicado níveis elevados de alguns compostos orgânicos e metais pesados em áreas próximas a aterros e no sangue de indivíduos residentes perto desses aterros". Assim sendo, parte-se do princípio que pode ser sugerido à gestão do aterro ASMOC e da Usina GNR Fortaleza, monitorar e avaliar com frequência a saúde da população do entorno desses equipamentos, assim como dos seus colaboradores internos, na busca por prevenir maiores danos à saúde física e mental desses atores sociais.

Segundo a World Health Organization (WHO, 2000), "qualquer exposição potencial a contaminantes existentes em depósitos de resíduos sólidos provavelmente deve estar confinada a um raio de $1 \mathrm{~km}$, considerando-se via aérea, e $2 \mathrm{~km}$, considerando-se a água como rota de exposição". Portanto, para a população do entorno do aterro e da usina, pode haver contaminantes no ar e na água no raio citado nesse local.

Nesse sentido, outra questão socioambiental que apresenta discrepância com a legislação ambiental, diz respeito aos dados do Estudo de Impacto Ambiental (EIA), no que se refere à distância mínima dos núcleos populacionais em relação ao aterro. De acordo com o EIA do ASMOC (ECOSAM, 2011, p. 454-455), no item 4.1 letra " $h$ ", recomenda-se que a distância mínima de núcleos populacionais deve ser superior a $500 \mathrm{~m}$ do limite da área útil de aterro sanitário. Portanto, a referida distância não cumpre com os critérios 
adotados pelas condicionantes vigentes sobre o projeto e a implantação da ampliação de um aterro sanitário - Norma ABNT NBR no 13.896/1997, nem com a distância determinada por diversos estudos de pesquisa citados no decorrer deste estudo e a exemplo do apresentado na Figura 1.

De acordo com a Figura 1, a distância entre as residências e o aterro ASMOC II é de aproximadamente entre 120 e $600 \mathrm{~m}$. Ou seja, totalmente em discordância com o que preconiza na legislação ambiental.

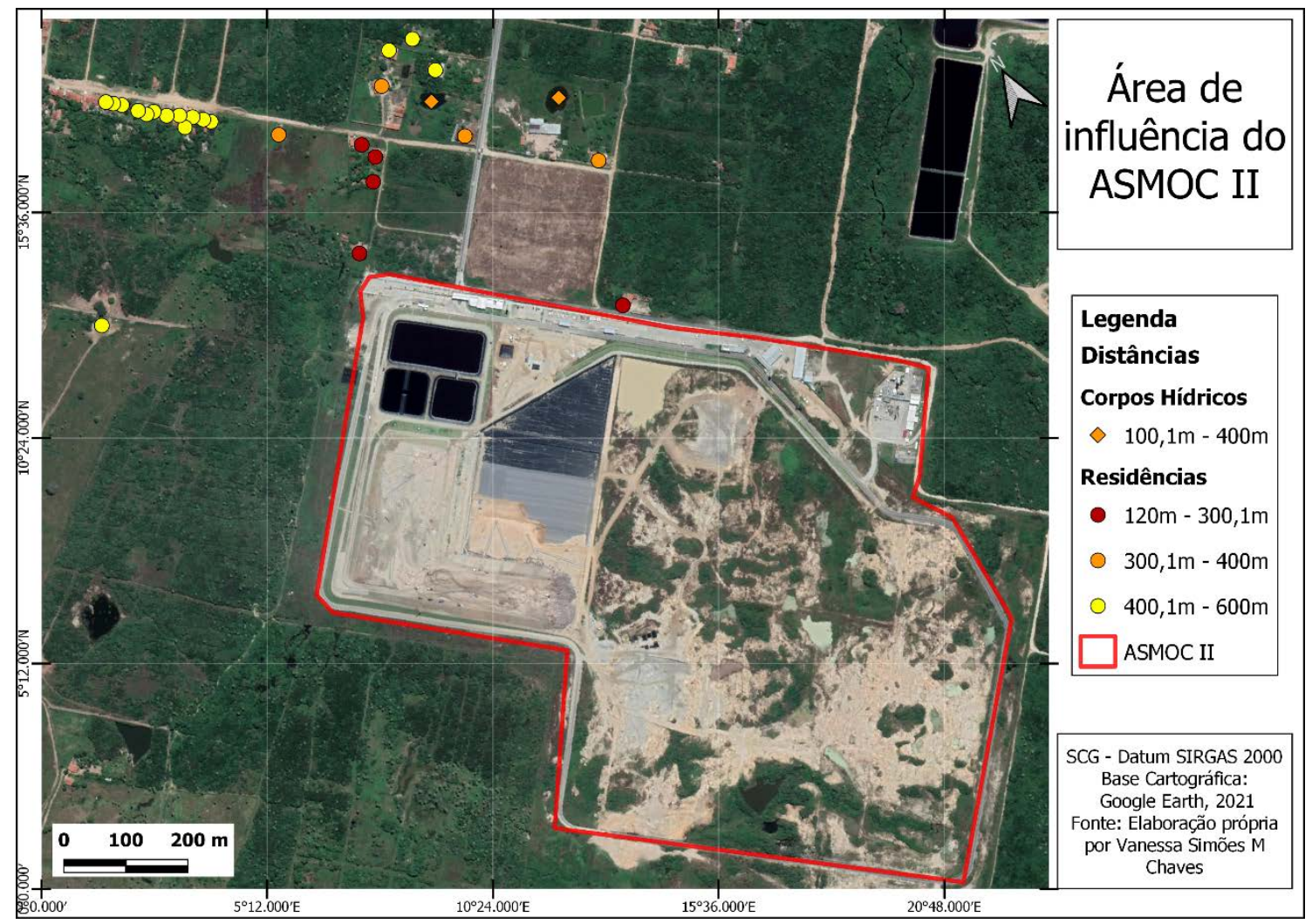

Figura 1. Distância entre as residências, os corpos hídricos e o Aterro Sanitário ASMOC II. 2021.

Diante do apresentado na Figura 1, observa-se que existem diversas residências no entorno do aterro sanitário ASMOC II, em raios não permitidos pela legislação ambiental. Observaram-se também corpos hídricos muito próximos do aterro. Observou-se que, mesmo a gestão do ASMOC e a Superintendência Estadual de Meio Ambiente (SEMACE), sabendo da existência das famílias ali residentes, foi realizada a instalação do ASMOC II. ASMOC I.

A Figura 2 apresenta a ocupação do entorno imediato do Aterro Sanitário do

A partir da Figura 2, e em visita in loco, observou-se que no entorno do ASMOC I, existem mais de cinco residências em um raio de $50 \mathrm{~m}$, ou seja, essas residências estão em um risco de contaminação e em desconformidade com a legislação ambiental. Essa situação de proximidade das residências ao aterro sanitário põe em risco a saúde da população do entorno. Verifica-se, portanto, que a gestão do ASMOC, bem como, a SEMACE, não cumpriram rigorosamente a legislação ambiental quando a fase de implantação do aterro sanitário na região. 


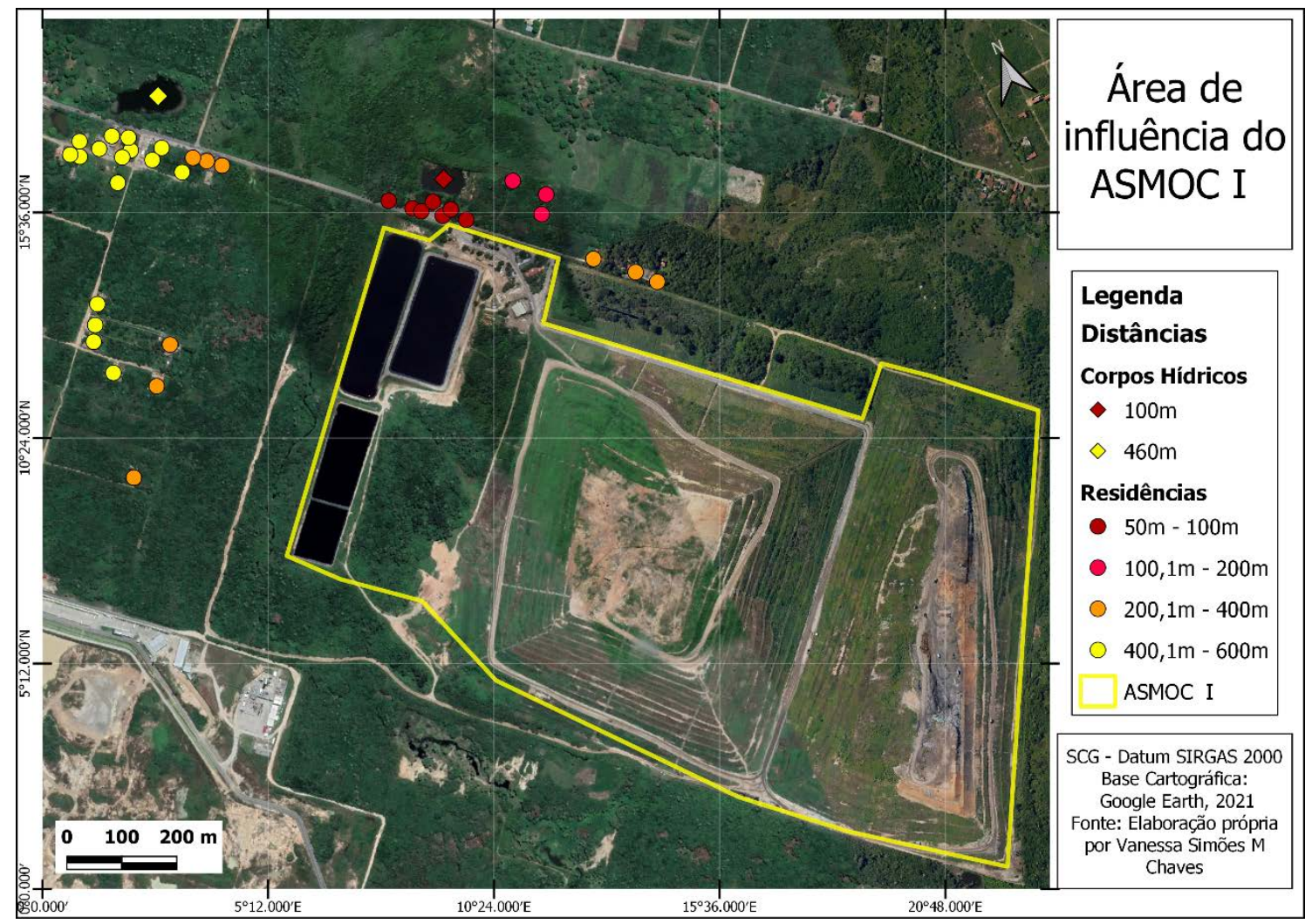

Figura 2. Distância entre as residências, os corpos hídricos e o Aterro Sanitário ASMOC I, 2021.

A Figura 3 apresenta residências a menos de um raio de $120 \mathrm{~m}$ do aterro sanitário ASMOC II. Como apresentado na Figura 3, existe residências ao lado do aterro sanitário.

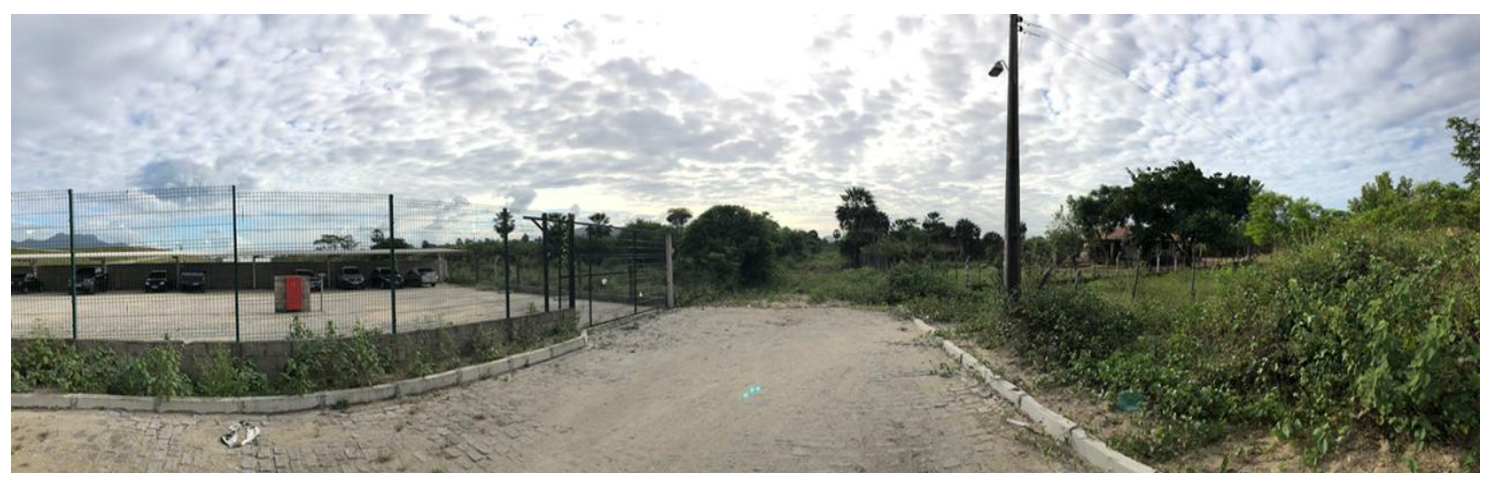

Figura 3. Distância entre as residências e o Aterro Sanitário ASMOC II, 2021.

Nesse sentido, foi observado que existem residências a $50 \mathrm{~m}$ da lagoa de chorume do ASMOC I e a 120 m do ASMOC II. O que de acordo com a legislação ambiental não é permitido. 
Não só as residências estão próximas ao aterro sanitário, mas também os corpos hídricos estão a um raio menor do que $100 \mathrm{~m}$ desobedecendo mais uma vez o EIA/RIMA do ASMOC (Figura 4).

Figura 4. Distância entre as residências, os corpos hídricos e o Aterro Sanitário ASMOC II, 2021.

A Figura 4 apresenta os corpos hídricos e as residências próximas ao aterro sanitário ASMOC, em um raio de aproximadamente $150 \mathrm{~m}$. Essa realidade revela o descumprimento da Legislação Ambiental e insuficiência da gestão municipal de Caucaia, no que diz respeito, a fiscalização e gestão do aterro sanitário. 0 próprio órgão licenciador, ainda na fase de Estudo de Impacto Ambiental(EIA) do ASMOC, por meio das análises laboratoriais apresentadas no EIA/RIMA, constatou impactos ambientais acima do permitido nos corpos hídricos desse local: esses resultados mostram que de acordo com a Resolução CONAMA no 357/2005 (Brasil, 2005), a Portaria SEMACE no 154/2002 (SEMACE, 2002) e a Resolução CONAMA no 430/2011 (Brasil, 2011), esta água encontrase imprópria e, portanto, não atende à Portaria da SEMACE, conforme indica Ensaios no EIA (ECOSAM, 2011, p. 442).

A mesma situação pode ser constatada próximo à Lagoa João Batista que fica a um raio de apenas $104 \mathrm{~m}$ do aterro sanitário ASMOC I (Figura 5). A gerência do ASMOC afirma que não tinha conhecimento do ocorrido. Dessa forma, percebe-se o quanto a população do entorno é invisível. 


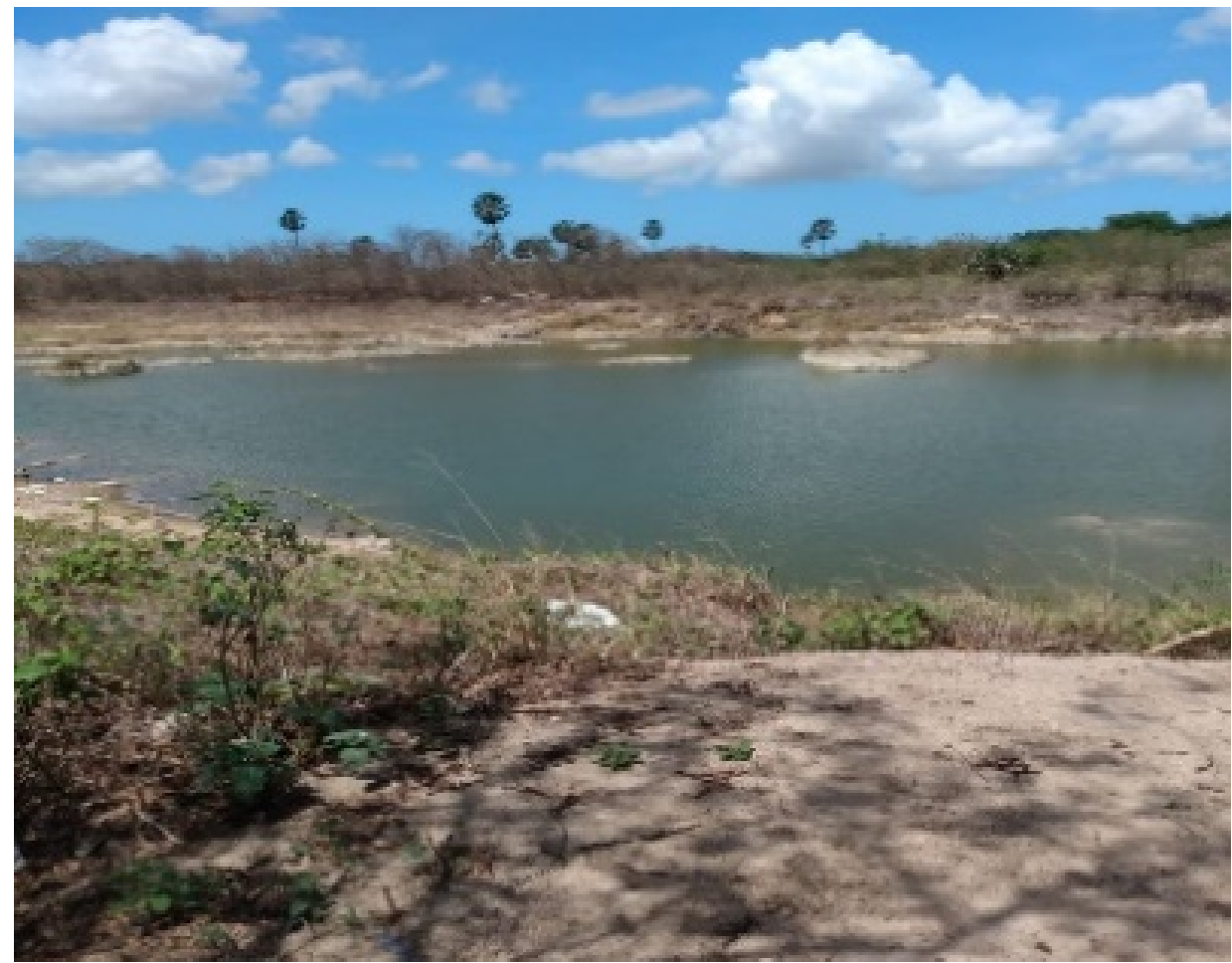

Figura 5. Distância entre a Lagoa João Batista e o Aterro Sanitário ASMOC I, 2021.

A instalação do aterro sanitário próximo a corpos hídricos a um raio mínimo de 104 m, a exemplo da Lagoa João Batista e a 460 m do Riacho Garoto, representa grande preocupação para a comunidade do entorno, assim como uma forma de negar o direito ao acesso à água potável que se tornou imprópria para o uso. Isso pode ser corroborado através das análises laboratoriais apresentadas no EIA/RIMA do ASMOC fora dos padrões estabelecidos de qualidade (ECOSAM, 2011, p. 442).

A instalação do ASMOC trouxe diversos conflitos socioambientais para a população local, a exemplo do que foi observado diante da fala da moradora Carolina Sales, percebeuse o quanto a memória, os laços familiares foram comprometidos. Fica também perceptível a invisibilidade social da realidade de vida dos moradores do entorno diante dos governos e gestores dos empreendimentos do aterro e da usina. Portanto, diversos são os conflitos socioambientais e econômicos existentes com a instalação e operacionalização do aterro e da usina. No aspecto físico a contaminação do solo e da água. No meio biótico não ter condições de realizar plantio porque a água existente na lagoa não permite irrigação. No meio antrópico é marcado pelo desemprego.

Nesse sentido, compreenda o porquê da terminologia ASMOC I e do ASMOC II desta área de estudo. Com o encerramento da vida útil do ASMOC, no ano de 2014, foi realizada a compra de um terreno com 23 ha ao lado desse aterro sanitário e instalou-se um novo aterro sanitário que de acordo com a licença de instalação passou a chamar Aterro Sanitário Metropolitano Oeste de Caucaia - ASMOC II. Nesse novo aterro sanitário instalouse a usina de biogás GNR Fortaleza com o objetivo de captar os gases gerados no ASMOC e produzir biogás ou biometano a partir do lixo. A Figura 6 apresenta esses espaços com mais detalhes. 


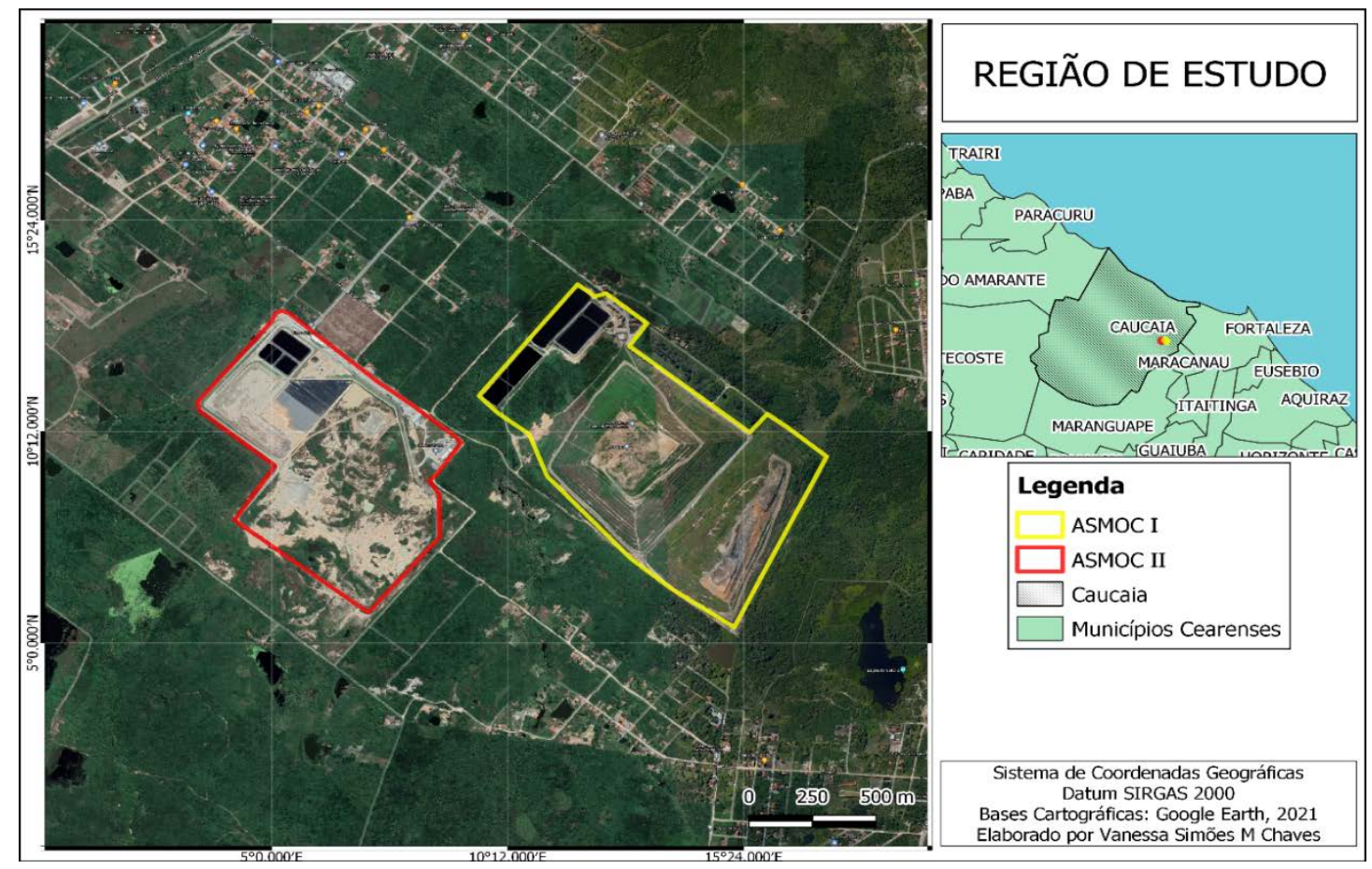

Figura 6. Mapa da Região de Estudo, 2021.

A seguir, a Figura 7 apresenta a ampliação do Aterro Sanitário Metropolitano Oeste de Caucaia - ASMOC II com seu funcionamento e uma visão panorâmica do seu entorno imediato (Fortaleza, 2012; SEMACE, 2019).

Figura 7. Aterro Sanitário Metropolitano Oeste de Caucaia- ASMOC II, 2021.

A Figura 8 apresenta a usina de biogás GNR Fortaleza e seu entorno. 


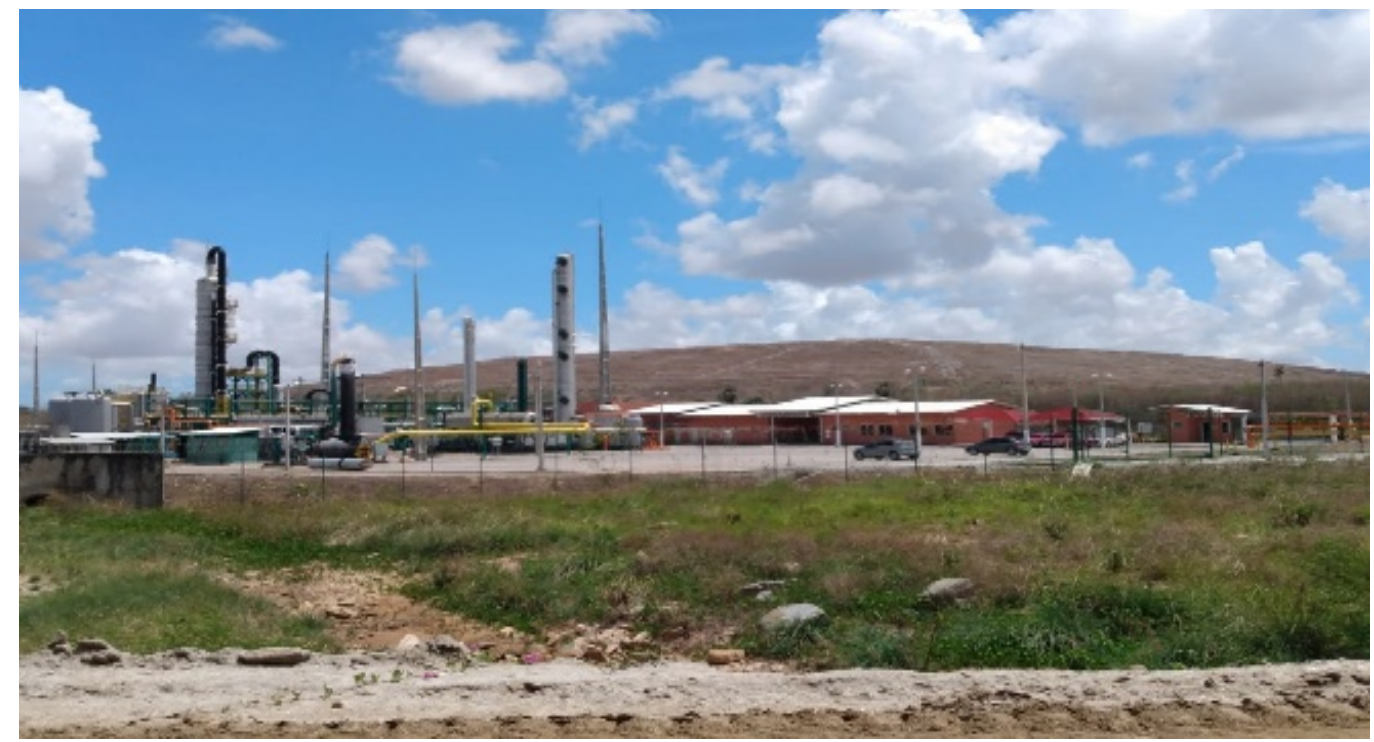

Figura 8. Usina GNR Fortaleza Valorização de Biogás Ltda, 2021.

A partir do que apresenta a Figura 8, percebe-se que a Usina GNR Fortaleza é instalada dentro do Aterro Sanitário ASMOC II.

\section{Semelhanças e diferenças entre o aterro ASMOC e a usina GNR Fortaleza com outros aterros sanitários no Brasil}

Para melhor compreender sobre os conflitos socioambientais com aterros sanitários no Brasil, apresenta-se a seguir a história de alguns aterros sanitários brasileiros a exemplo do Aterro Sanitário de Puxinanã-PB, do Aterro Sanitário da Caximba, de Curitiba-PR, do Aterro Sanitário Cruz das Almas-BA e do Aterro Sanitário Municipal Bandeirantes de São Paulo-SP.

A partir do que estar apresentado, conhecer a problemática de implantação e operacionalização de outros aterros sanitários e usina de biogás de outras cidades contribuíram para perceber as semelhanças e diferenças na comparação do aterro ASMOC e da usina GNR Fortaleza.

Neste sentido, ao pesquisar sobre os conflitos socioambientais no Aterro Sanitário de Puxinanã, de acordo com Guedes e Ribeiro (2017) é a partir da localização do Aterro Sanitário de Puxinanã-PB, dentro da bacia hidrográfica do principal manancial que abastece toda a população urbana do Município de Puxinanã, que se efetiva vários conflitos socioambientais. O Açude Evaldo Gonçalves, popularmente conhecido como Açude da Milhã, é responsável pelo abastecimento público de água de toda a população urbana da cidade, de acordo com o parecer técnico da Superintendência de Administração do Meio Ambiente (SUDEMA, 2011). Segundo Guedes et al. (2017), a população tem sido prejudicada no que se refere às questões ambientais da área do entorno do Aterro Sanitário Puxinanã, tendo em vista a deterioração dos sistemas ambientais do meio físico a água, ar e solo, assim sendo, é possível perceber inúmeros problemas no que se refere à elaboração e concessão das licenças prévia (LP), licença de instalação (LI) e licença de operação (LO).

$\mathrm{Na}$ busca por fundamentar as informações no que diz respeito aos conflitos socioambientais no Aterro Sanitário da Caximba de Curitiba-PR, localizado ao sul do Município de Curitiba, no Bairro da Caximba, entre os Municípios de Araucária e Fazenda Rio Grande, apresenta vários conflitos socioambientais com relação à preservação e conservação dos mananciais e a gestão territorial. Esta região também abriga rios de 
potencial relevante como o Rio Iguaçu, principal corpo hídrico que é utilizado para abastecimento público e um dos principais afluentes do Rio Paraná, principal formador da Bacia do Prata. A área destinada à expansão do aterro pertence a APA Municipal do Iguaçu, muito embora tenha sido criada após a implantação do aterro sanitário. Essa área perde sua função uma vez que há contaminação causada pela Estação de Tratamento do aterro. Assim sendo, há grandes riscos de contaminação do Rio Iguaçu, do lençol freático e mananciais, haja vista existir três nascentes do Rio Iguaçu dentro do referido aterro sanitário, dessa forma não atendem os padrões legais (Resolução CONAMA no 357/2005) de emissão de efluente. 0 Aterro da Caximba está em área de recarga do Sistema Aquífero Guarani, sendo que o aquífero subterrâneo consiste em uma alternativa de abastecimento público para o continente sul americano (Brito, 2005; Porto e Martinez-Alier, 2007).

Ainda na busca por pesquisar sobre os conflitos socioambientais, de acordo com Souza e Teixeira (2012), o Aterro Sanitário Cruz das Almas possui vários conflitos socioambientais, a iniciar por sua localização próxima a riachos e brejos, ou seja, podendo representar vários riscos à saúde humana, poluir a água, ar e solo, assim como ser situado a menos de 500mde uma área residencial. 0 fato de seus resíduos de serviços de saúde, resíduos de abate, pneus encontrarem-se expostos também apresenta altos índices de contaminação, assim como, ter a queima dos resíduos a céu aberto. A presença de animais e pessoas na área de disposição dos resíduos sólidos é outro fator agravante de gestão socioambiental.

Outro conflito ambiental observado no aterro sanitário de Cruz das Almas na Bahia é o fato doaterro não apresentar a Licença de Operação (LO) caracterizando descumprimento das legislações ambientais vigentes (CEAMA, 2007; Souza e Teixeira, 2012).

De acordo com o "Relatório Desafio do Lixo", do Ministério Público do Estado da Bahia (MPBA, 2007, p. 37), os centros urbanos devem ter distância mínima de 2 km de aterros sanitários e lixões, haja vista o fato de proximidade inferior a citada implicarem em maior incômodo à população, a exemplo do aterro sanitário de Cruz das Almas na Bahia (MPBA, 2007; Souza e Teixeira, 2012).

0 Aterro Sanitário do Município de Cruz das Almas não atende à determinação da Resolução CONAMA no 404/2008 (Brasil, 2008), que dispõe em seu capitulo XV sobre programa de educação e coleta seletiva:

A apresentação de programa de educação ambiental participativo, que priorize a não geração de resíduos e estimule a coleta seletiva, baseado nos princípios da redução, reutilização e reciclagem de resíduos sólidos urbanos, deve ser executado concomitantemente à implantação do aterro (Brasil, 2008).

Segundo Quintas (2004) a educação ambiental surge como uma alternativa a degradação do meio natural, que tem como consequência a contestação do desperdício e consumismo como ações básicas desse processo. Dessa forma, se cada um consumisse apenas o necessário, utilizasse a política dos 3 Rs, reutilizar, reciclar e reduzir ou transformar os rejeitos em coisas úteis, de fato estaríamos contribuindo com a economia de energia e recursos naturais, assim como mitigando os impactos socioambientais. Sabese que a educação ambiental de forma contínua é capaz de promover mudança comportamental e, assim sendo formar hábitos ambientalmente adequados ao meio social, econômico, político, de direito, cultural e a visão crítica acerca da problemática ambiental.

De acordo com a Conferência de Tbilisi (1977) a Educação Ambiental (EA) é considerada como sendo:

Um processo permanente no qual os indivíduos e a comunidade tomam consciência de seu meio ambiente e adquirem o conhecimento, os valores, as 
habilidades, as experiências e a determinação que os tornam aptos a agir individual e coletivamente- a resolver os problemas ambientais presentes e futuros. É importante implantar a política dos 3 Rs: Reduzir o consumo, reaproveitar e Reciclar os resíduos (Dias, 1992; Pelicione, 1998; Carvalho, 2016).

Apesar de existir a Política Nacional de Educação Ambiental, regulada pela Lei $\mathrm{n}^{\mathrm{o}}$ 9.795/1999 (Brasil, 1999), o Município de Cruz das Almas ainda não tem programas de educação ambiental de forma contínua e, dessa forma se identifica com o município de Fortaleza no Estado do Ceará.

Na tentativa de contribuir com a pesquisa no nosso objeto de estudo, foi elencado osconflitos socioambientais na usina Central Termelétrica Biogás a partir do lixo do aterro sanitário municipal Bandeirantes em São Paulo-SP, localizado no km 26 da Rodovia dos Bandeirantes, no distrito de Perus no Estado de São Paulo recebe em torno de 7 mil toneladas diárias de lixo e é considerado um dos maiores do mundo, de acordo com a Companhia de Tecnologia de Saneamento Ambiental. 0 referido aterro teve sua vida útil de 1975 a 2005 e, deixou ali depositado um total de 30 milhões de toneladas de resíduos sólidos. Neste mesmo aterro, em janeiro de 2004 foi instalada a Central Termelétrica Biogás de $20 \mathrm{MW}$, que proporciona a geração de mais de $170.000 \mathrm{MWh}$ de energia elétrica, o suficiente para abastecer uma cidade de 400 mil habitantes, por meio do tratamento do lixo e o isolamento do metano, além de proporcionar os impactos positivosnas esferas social, global, ambiental, econômico e local, o meio biótico foi contemplado com a diminuição das moscas,dos insetos, das doenças e do odor gerando uma contrapartida social e econômica. Sabe-se ainda, que os gases gerados nesse aterro reduzirão a emissão equivalente a 8 milhões de toneladas de gás carbono no período de 15 anos, contribuindo assim para a mitigação do efeito estufa (CETESB, 2004).

São Paulo é a segunda cidade brasileira a produzir gás natural advindo do lixo de aterro sanitário, ou seja, por meio dessa prática mitiga as emissões de gases de efeito estufa e evita o uso de combustível fóssil. Para a Secretaria de Energia e Mineração, a cidade de São Paulo na região Sudeste do Brasil é a maior consumidora de gás natural, e que utiliza anualmente aproximadamente 6 milhões de metros cúbicos, por meio de três áreas de concessão acerca de gás canalizado. As referidas áreas são administradas pelas empresas Comgás, Gás Brasiliano e Gás Natural Fenosa (SEBIGASCOTICA, 2017).

0 referido aterro sanitário tem apresentado vários conflitos socioambientais. Segundo o Centro de Estudos da Metrópole (CEM), o Distrito possui duas grandes favelas, o Recanto do Paraíso e o Recanto dos Humildes. Seus moradores além de sofrerem com a presença do tráfico de drogas e do crime, esses locais são próximos a área do aterro Bandeirantes; segundo o Fórum de Perus e Anhanguera (2007, p. 2), o Projeto de Mecanismo de Desenvolvimento Limpo (MDL) do Aterro Sanitário Bandeirantes" Consórcio Biogás, Unibanco e Prefeitura Municipal de São Paulo, descumpriram os Anexos do Tratado de Kyoto: a ausência da participação popular na condução do Projeto MDL e o fato do dinheiro gerado ter sido destinado exclusivamente para a Secretaria do Verde e Meio Ambiente, o que dificultou seu uso na geração de emprego e renda. Outro impacto negativo observado, apesar da grande capacidade produtiva da usina, a população de Perus paga a conta de energia, enquanto que o Unibanco tem energia elétrica gratuita (Forum de Perus, 2009).

Nesse contexto, as comunidades das favelas do Recanto do Paraíso e o Recanto dos Humildes são injustiçadas socioambientalmente de forma que os atores sociais mais ricos têm mais acesso e consomem mais a natureza do que os pobres. Essas comunidades pagarão mais caro pelo uso da energia elétrica que é produzida na mesma localidade de suas residências. 
Diante do exposto, percebeu-se que constatar os conflitos socioambientais é tarefa importantíssima para condução do processo de instalação e operacionalização de empreendimentos, a exemplo de aterro sanitário e de usina de biogás advindo de lixo.

Nesse sentido, para a realização deste estudo de pesquisa junto aos atores socias envolvidos neste trabalho, recorreu-se à Ecologia Política que, por sua vez vem para perceber as entrelinhas da relação de poder existente diante dos recursos naturais e as ações humanas, na busca por denunciar, dar visibilidade aos mais vulneráveis, os que não têm vez e nem voz, os que têm seus direitos coletivos negados pelos que detém o poder político e social. $O$ item a seguir apresenta essa relação socioambiental dos atores sociais envolvidos nesta pesquisa.

\section{Atores sociais: população do entorno}

A área em discussão desta pesquisa, apesar de ser ocupada pela população, essa área foi demarcada para a instalação do aterro sanitário ASMOC e posteriormente foiinstalada uma usina de biogás para a produção de biometano, ou seja, nesse espaço aconteceram dois processos de mudanças ambientais e vários processos de territorialização, a exemplo de desapropriação de moradores dos seus terrenos para ocupação com o aterro sanitário ASMOC que resulta na injustiça ambiental que fragiliza cada vez mais os mais pobres, assim como a relação dos laços familiares e culturais no convívio diário com os seus, ou seja, a família do entorno ficou fragmentada com a instalação do aterro sanitário. Pais e filhos tiveram que se separar, pois a casa já não podia existir no referido espaço, tendo em vista a ocupação do aterro sanitário. As plantações de árvores frutíferas também não puderam mais existir. Com isso, evidencia-se o processo de territorialização, o que para Leff (2006) esse espaço contempla simultaneamente o ambiente físico e as relações sociais, e para Raffestin (1993), afirma que a partir do momento que o espaço é apropriado pelos atores sociais, concreta ou simbolicamente, ele torna-se um território, expressando assim, as relações de poder que referenciam o controle e a gestão do espaço. Embora, diante do pesquisado junto à população do entorno da usina e do aterro, um dos moradores do entorno, dissera que a dor não pode ser externalizada, é "preferível manter- se em silêncio, tenho medo de falar o que sinto pelo fato de um único filho que trabalha no local perder seu emprego de um salário mínimo" (Raffestin, 1993; Ferreira et al., 2013).

Nesse sentido, o silêncio de que fala o ator social, pode estar evidenciado no que diz Acselrad (2010, p.114), "a desigualdade resultaria, nesse caso, da menor capacidade de os moradores dessas periferias se fazerem ouvir nas esferas decisórias ou mesmo de seu consentimento - dada a carência de emprego, renda". Sabe-se que o ator social deixa claro na sua fala que a situação de desigualdade social vivida por sua família, não pode ser externalizada tendo em vista o medo de que o único filho que está empregado no empreendimento possa ser desempregado. Por isso, diante do medo fica calado, mesmo sofrendo as consequências de injustiça social e ambiental, a exemplo do risco à saúde pelo fato da água ser considerada imprópria para o uso humano, o risco de perder o emprego, das más condições de saúde, dentre outros conflitos e impactos socioambientais.Para Tuan (2005, p.07), "os medos são experimentados por indivíduos e, nesse sentido, são subjetivos; alguns, no entanto, são, sem dúvida, produzidos por um meio ambiente ameaçador". Isso se afirma quando o ator social diz não denunciar a situação de degradação ambiental e de impacto social por ter medo de perder o único emprego da família de cinco filhos.

Nesse sentido, evidenciou-se esse sentimento de perda social e ambiental como revelado pela moradora Carolina Sales que tem 59 anos, cursou até a $3^{\underline{a}}$ série do Ensino Fundamental dos Anos Iniciais. Ela tem cinco filhos, destes somente um estuda. Sobrevive com uma renda mensal de $\mathrm{R} \$ 500,00$ (quinhentos reais). Disse viver muito insatisfeita porque somente um filho trabalha no aterro sanitário e a renda familiar é insuficiente. Sua 
maior tristeza é ter visto o seu pai perder suas terras para ser instalado o aterro sanitário e "nunca ter recebido nenhum benefício por suas terras". Sente-se enganada, desassistida e prejudicada. Disse também que sente fortes dores de cabeça, problemas respiratórios e atribui tudo isso ao mal cheiro do aterro sanitário e a poluição do ar. Há 59 anos mora no mesmo lugar que nasceu. Chegou ao bairro Carrapicho antes da instalação do aterro. Dona Carolina Sales reclama da vida sofrida e por ter seu direito negado e também ser muito pobre. A sua residência fica a $10 \mathrm{~m}$ do aterro sanitário e atribui os incômodos à sua saúde por morar praticamente dentro do aterro sanitário. Nesse contexto, “o grau de contaminação e poluição é muito grande", disse Dona Carolina.

A desigualdade socioambiental é visível nos entrevistados da população do entorno do ASMOC, cem por cento da referida população cursou apenas o Ensino Fundamental Anos Iniciais incompletos. 0 que comunga com o que afirma Almeida (2009), "o Brasil se caracteriza por ser um país de grande desigualdade social, no qual grande parcela da população vive em condições de pobreza, sendo também um país que apresenta elevada taxa de analfabetismo".

Outros riscos observados dizem respeito ao risco da insegurança alimentar tendo em vista não ter renda suficiente para o sustento da família com o pequeno salário, assim como, ocorre o risco ambiental, ao se referir as águas do entorno por estarem impróprias para o uso humano e outro risco ambiental observado é o fato das residências estarem a menos de $10 \mathrm{~m}$ da entrada do aterro sanitário, assim como o risco de saúde por terem olfato afetado com o mal cheiro do chorume e, por último o risco econômico, haja vista da dependência do emprego do filho no aterro sanitário, ou seja, existem diversos riscos à população do entorno do aterro sanitário e da usina de biogás.

Para Egler (2005) e Thouret (2007), existem diversos tipos de riscos, a exemplo de risco da insegurança alimentar, o risco ambiental, o risco de saúde, o risco social e o risco econômico. No que se refere ao risco social é aquele que é:

Resultante das carências sociais ao pleno desenvolvimento humano que contribuem para a degradação das condições de vida. Sua manifestação mais aparente está nas condições de habitabilidade, expressa no acesso aos serviços básicos, tais como água tratada, esgotamento de resíduos e coleta de lixo (Egler, 2005, p. 4).

Diante do pesquisado, percebeu-se que na região do entorno do aterro ASMOC, a população vive sem pavimentação das ruas e nem esgotamento de resíduos, o que para Egler (2005), o "risco social está intimamente ligado à pobreza". Segundo Thouret (2007), a pobreza se constitui também um fator de risco, mais especificamente aquela que habita nas periferias, nas favelas e nas áreas de vulnerabilidade. De modo que o risco social e o risco ambiental possam ser percebidos de forma associada e afirma:

A pobreza constitui um triplo fator de risco: ela força as pessoas a viverem nas zonas menos caras, mas mais perigosas; ela domina as preocupações cotidianas das pessoas que não têm nem os recursos econômicos nem tempo de preservar o meio ambiente; ela força o desbravamento e o desflorestamento para atender às necessidades fundamentais de aquecimento e alimentação. As degradações do meio urbano são também consideradas por vários autores como riscos: ainda que lentas, elas acarretam acidentes indiretos (por exemplo, a obstrução de redes de drenagem urbana) e favorecem acidentes diretos e mortais (afundamentos do pavimento, deslizamentos dos aterros e de obras de contenção) (Thouret, 2007, p. 24).

A população do entorno encontra-se numa área que representa riscos à saúde por residir a menos de $50 \mathrm{~m}$ do aterro sanitário, o que não é permitido pelas leis ambientais. 
Dessa forma, percebe-se a existência da injustiça social, da concentração de renda e a falta de fiscalização das políticas públicas de habitação, assim como por não ter ninguém para denunciar esse tipo de situação das residências num raio inferior ao estabelecido pela legislação ambiental.

Durante a realização da entrevista e a aplicação de questionário junto à população do entorno, em março de 2020, a exemplo de Mário Rodrigues Silvestre, Lucas Pereira Sousa, Geraldo Pereira Vieira e Carolina Alves Sales, observou-se que a maioria dessa população do entorno vive de pequenos salários. Todos os entrevistados cursaram o Ensino Fundamental incompleto e que a vida é precária no que se refere ao acesso aos direitos fundamentais naquele lugar. A poluição sonora causada pelo grande fluxo de caçambas e carros compactadores que transportam os resíduos sólidos urbanos e domiciliares até ao aterro, incomoda demais durante $24 \mathrm{~h}$ a população do entorno, assim como o mal cheiro advindo da decomposição dos resíduos por meio do chorume ou lixiviado.

Nesse sentido, antes de iniciar o processo de aplicação de questionários e realização das entrevistas, fez-se uso do termo de Consentimento Livre Esclarecido e da Carta de Anuência, que são instrumentos que asseguram a redução de riscos aos sujeitos pesquisados, por meio de autorização por escrito, assim como, para a identificação desses atores sociais envolvidos nesta pesquisa, optou-se por usar nomes fictícios. A pesquisa foi aprovada pelo Comitê de ética da Universidade Federal da Paraíba.

Dessa forma, para poder entender a situação de impactos e conflitos existentes com a população do entorno, Acselrad e Kalecki (1987) trazem suas contribuições afirmando que, segundo Acselrad (2013, p. 118), a situação de desigualdade trata-se de "uma imposição desigual de riscos, não só no que diz respeito a salários, mas também nos direitos destinados a assegurar proteção social e ambiental". O que para Kalecki (1987), essa realidade pode ser entendida como a transformação da força econômica do capital dos que detém o poder, em força política. Ainda para fundamentar a realidade vivida pelos atores sociais do entorno da usina e do aterro, Martinez-Alier (1992) vem dizer da importância das contribuições do ecologismo dos pobres na perspectiva de se fazer necessária às lutas ambientais e sociais na busca por justiça social no Terceiro Mundo. Portanto, é também a partir do ecologismo dos pobres que se faz anunciar as liberdades por meio de movimentos ecologistas trazendo à tona as contribuições com suas ações para evidenciar os custos que empresas ou serviços estatais devem pagar ao degradar o meio ambiente.

Diante das condições sociais e ambientais observadas nesta pesquisa, sinaliza-se que existe percepção de riscos sociais e ambientais com a população do entorno da usina e do aterro. Segundo Veyret (2007), o risco ocorre quando coloca em perigo um indivíduo ou uma coletividade, o que se confirma com a poluição sonora tendo em vista o fluxo de caçambas e carros compactadores, tão percebida pela referida população, assim como, o fato da água do Riacho Garoto e da Lagoa João Batista estarem imprópria para o uso humano e existência da vida animal, a exemplo de peixes.0 que ainda se confirma com o mal cheiro vindo do chorume, que pode trazer risco à saúde. Diante desse contexto, muitos atores sociais reclamam de dor de cabeça tendo em vista esse mal cheiro muito forte.

De acordo com Veyret (2007, p. 11), o "risco é a tradução de uma ameaça, de um perigo para aquele que está sujeito a ele e o percebe como tal", o que se afirma diante da situação da família do ator social supracitado, pelo fato da água está impropria, representando uma ameaça para a saúde. Para Giddens (1991), existe risco que surge a partir de uma ação criada no ambiente e que é chamado de risco derivado do meio ambiente. Assim sendo, o risco relacionado ao fluxo dos veículos, o risco causado pela decomposição dos resíduos (mal cheiro do chorume) e a inviabilidade do uso da água, estão relacionados aos riscos derivados do meio ambiente. 
0 ator social Geraldo Pereira Vieira é um dos moradores questionados. Ele tem 38 anos de idade e sua profissão é pedreiro e sua renda mensal é de $\mathrm{R} \$ 400$ reais. Falou que vive no entorno da usina há mais de 10 anos. Cursou até a $2^{\underline{a}}$ série do Ensino Fundamental Anos Iniciais. Quando indagado sobre o que representa a usina de biogás GNR, ele respondera que a vida da comunidade havia melhorado porque tinha gerado emprego e renda, embora na casa dele ninguém trabalhe no aterro. Dissera que a vizinha dele conseguiu trabalho no aterro sanitário onde fica a usina GNR. Com a chegada da usina mitigou a emissão dos gases de efeito estufa a exemplo do metano e gás carbônico, ou seja, diminuiu a poluição do ar. Falou ainda sobre o aumento da população naquela comunidade e com isso aumentou também seus serviços na área da construção civil. Quando foi perguntado sobre se havia ou não desaparecido árvores e animais, com a chegada da usina, ele respondera que não.

Para o ator social Mário Silvestre, morador que há mais de 22 anos reside no bairro do entorno da usina de biogás, a vida melhorou com a chegada da usina GNR. Seu grau de escolaridade foi até a $5^{\underline{a}}$ série do Ensino Fundamental Anos Iniciais. Sua profissão é comerciante de um pequeno bar e marmitaria. A sua clientela é composta por funcionários do aterro sanitário e da usina. 0 fornecimento de alimentação, a exemplo de almoço, caldo, merenda, bolo e bebidas no seu empreendimento dá para sustentar sua família. A renda mensal é R \$ 1.500. Perguntado sobre o desaparecimento de animais e plantas frutíferas, ele respondeu que não tem percebido. Para ele as coisas continuam como antes nesse aspecto, o que tem de negativo é o odor desagradável do aterro sanitário, mas que ele já estava acostumado. Nesse local tem criado seus cinco filhos e desses três estudam.

Outro ator social entrevistado foi o senhor Lucas Pereira Sousa que há mais de 29 anos reside no local, antes mesmo da existência do aterro sanitário do ASMOC. Para o senhor Lucas a vida só melhorou com a chegada da usina de biogás, por ter gerado emprego e renda e extrair o gás natural advindo do lixo, diminuindo a poluição. A sua mercearia teve um relevante crescimento. A sua residência e comércio ficam em frente à via que dá acesso à entrada do novo aterro sanitário e com isso percebeu-se uma elevada poluição sonora com o grande fluxo de caminhões, carros compactadores e caçambas no transporte dos resíduos sólidos. Assim como grande mau cheiro advindo do chorume do aterro. Tendo em vista ser uma via muito estreita, a passagem de pedestre fica prejudicada haja vista o risco com o grande tráfego de veículos. Lucas tem cinco filhos entre estes um Técnico em Radiologia e outro Técnico em Enfermagem. Nenhum dos filhos reside no bairro. Na comunidade do entorno existe muitos parentes de Lucas. A Figura 9 a seguir mostra a via que dá acesso ao aterro sanitário ASMOC e a Usina de biogás GNR Fortaleza.

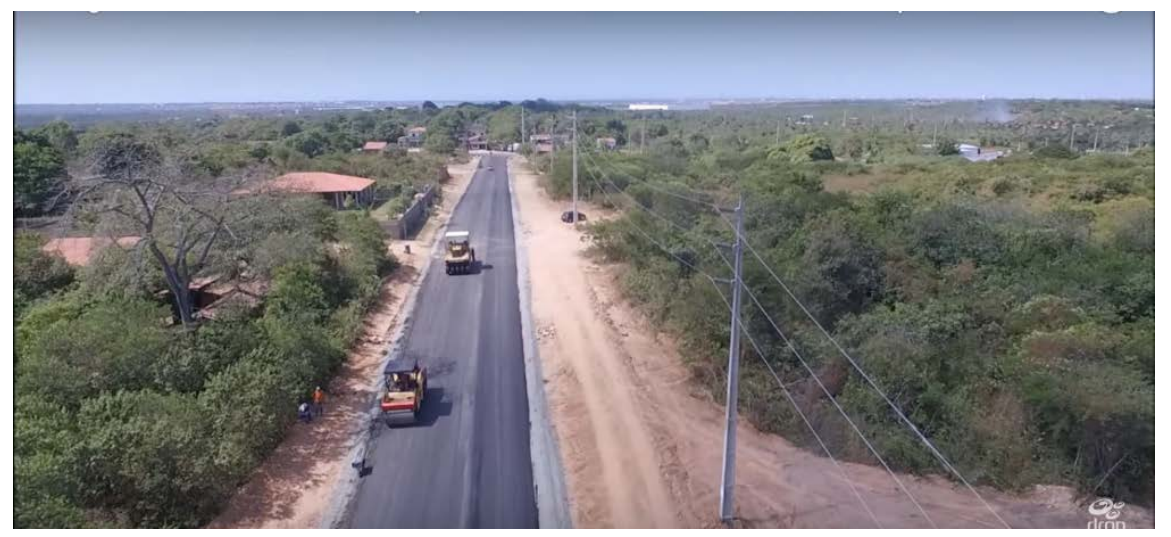

Figura 9. Via de acesso ao aterro sanitário ASMOC, a usina de biogás e as residências do entorno. 2017. 
Na Figura 9é possível ver o quanto as residências ficam próximas do aterro sanitário do ASMOC I e II e da Usina de Biogás. E, assim sendo, muito mais próximas dos ruídos advindos da usina, do odor desagradável da decomposição de resíduos sólidos do aterro sanitário, assim como do barulho dos carros que transportam os resíduos até o aterro sanitário durante $24 \mathrm{~h}$ em todos os 365 dias do ano.

De acordo com o Mapa da Injustiça Ambiental e Saúde no Brasil (2020), este revela que as principais populações vítimas de injustiças ambientais são os moradores do entorno de aterros sanitários e lixões, bem como operários e trabalhadores das indústrias. E isso se confirma quando dos resultados das entrevistas onde a maioria dos moradores do entorno tem uma renda insuficiente para sua sobrevivência, outros foram desapropriados, vivem inalando diariamente o mal cheiro do lixiviado que é emitido no ar, ainda por estarem sujeitos a terem suas moradias invadidas por insetos, moscas, baratas, ratos e formigas advindas do lixo do aterro sanitário ASMOC.

\section{Atores sociais: diretoria e engenheiros químicos da usina GNR Fortaleza}

Baseado nos questionários aplicados e realização de entrevistas à diretoria e analistas de operações para se obter informações sobre a usina de biogás GNR Fortaleza, obteve-se os seguintes resultados.

A Diretoria e Analistas de produções quando questionados sobre quanto tempo trabalhavam na GNR Fortaleza, ambos responderam que há dois anos dedicavam seu trabalho junto à referida usina, haja vista a inovação do processo e sustentabilidade do empreendimento, os desafios diários, o fato de ser uma área nova em constante aprendizado. A perspectiva em relação ao uso do biometano no Brasil será de crescimento, pois se mostra que este é viável, assim como o aumento da produção nos próximos anos tendo em vista cada vez mais o ser humano gerar resíduos sólidos. Embora, mesmo sabendo que os maiores entraves para a produção do biometano esteja na falta de incentivo da regulação que obrigue distribuidoras de gás a comprar biometano disponível e mais de $99 \%$ dos municípios brasileiros não terem um aterro tão grande, a exemplo do ASMOC, no município de Caucaia. Os municípios precisariam juntar seus lixos para ter um aterro grande o suficiente para gerar um volume alto de biogás de forma que fosse $o$ suficiente e assim ser viável colocar uma usina de biogás.

Ao serem questionados sobre os impactos positivos na GNR Fortaleza, foi informado que, além de mostrar para o Brasil que é possível ter certo nível de cadeia sustentável, gera-se impostos para o Estado do Ceará , emprego e renda e ainda se evita de jogar na atmosfera gases que ajudam no efeito estufa, e que exalam mal cheiro,assim como, comprova-se a viabilidade de produzir biometano em larga escala no Brasil e evita importação de gás natural. Com relação aos impactos negativos, a resposta foi de que "não consigo visualizar impactos negativos". Embora, não é exatamente isso que foi observado nesta pesquisa, tendo em vista a invisibilidade da Família de uma das entrevistadas, a Dona Carolina Sales que na sua casa de cinco membros, apenas um membro tem emprego, implicando em um risco social e econômico (Thouret, 2007).

A usina de biogás GNR Fortaleza tem como referência exitosa fora do Brasil, os exemplos de produção na Alemanha, na Holanda, nos Estados Unidos, com suas plantas de purificação operadas pela Morrow Renewables, dentre outras. No campo da comercialização, a GNR, traz como vantagens, complementar o suprimento de gás da Petrobras que tem limitado a oferta de novos volumes para o Estado do Ceará. Outra vantagem elencada pelos entrevistados é o acesso a incentivo fiscal do ICMS, que, segundo legislação do município de Fortaleza, este se beneficia de uma taxa sobre o biometano produzido na referida usina. Outra vantagem elencada é a geração de emprego e renda. Desde a implantação aos dias atuais foram gerados 28 empregos diretos e 30 indiretos, sendo dois funcionários do sexo feminino e 26 do sexo masculino. Também, contratou-se um número significativo de funcionários que residem no entorno da usina. Sabe-se que a 
empresa disponibiliza EPIs para os funcionários a exemplo de máscaras de gases, capacete, óculos segurança, vestimentas adequadas ao serviço, luvas, protetores auriculares, botas, analisadores de gases, sinto de segurança, fardamento, cinta ergonômica, dentre outros e que estes têm uma jornada de trabalho de $12 \times 36 \mathrm{~h}$ para os que trabalham na planta de purificação de biogás , para os operadores de captação e setor administrativo são $44 \mathrm{~h}$ semanais, de segunda a sexta das 07:30 h às 17:00 h e aos sábados de 07:00 h às 11:00 h. Com relação à formação, qualificação e/ou treinamento para seus colaboradores, a empresa realiza semestralmente e que aponta como consequências mais consciência , segurança e produtividade nas atividades.

Ao serem questionados sobre com que periodicidade é verificada na GNR Fortaleza, se está acontecendo a implantação das medidas de segurança, referente ao Sistema de Proteção de Descargas Atmosféricas (SPDA) e Sistema de Proteção contra Incêndio, estabelecidos pelo Código de Segurança Contra Incêndio do Corpo de Bombeiros e das Recomendações para Redução do Risco, elencadas nas planilhas da Análise Preliminar de Perigos (APP) do Estudo de Risco, obteve-se como reposta de que a avaliação da malha de aterramento e sistema SPDA são realizadas anualmente por empresa especializada que emite laudo informando os resultados nos diversos pontos analisados, indicando onde há necessidade de intervenção. Com relação ao laudo de AVCB dos Bombeiros tem validade a cada dois anos quando as medidas preconizadas são reavaliadas. Para saber se há ou não um vazamento em uma linha de processo, em uma tubovia, fundo ou topo de um reservatório, dentre outros, para isso, são realizadas inspeções rotineiras pelo pessoal de operação e manutenção dos principais equipamentos e tubulações da planta. São usados equipamentos de ultrassom, tubos dragger de identificação de gases, analisadores portáteis de gases. Faz-se também o balanço de massa usando os medidores de vazão para detecção de alguma perda de processo fora do normal. Os operadores utilizam detector Monogás de $\mathrm{H}_{2} \mathrm{~S}$. Nessa perspectiva, foi informado que desde as instalações da GNR Fortaleza nunca houve princípio de incêndio em poça, nem tão pouco incêndio em nuvem.

Ao questionar Paulo Vieira Nunes, da diretoria da usina de biogás é possível perceber a satisfação em fazer parte da usina de GNR Fortaleza, tanto por pertencer a um empreendimento com alta rentabilidade quanto pela ação da mitigação dos gases de efeito estufa no espaço da usina de biogás. Segundo Paulo Nunes, a usina deve emitir cerca de 90 mil Créditos de Descarbonização (CBIOS), de modo a injetar na empresa cerca de $\mathrm{R} \$ 3,6$ milhões. Ainda pode impactar na atração de investimentos externos com a venda dos créditos no mercado financeiro, assim como propor um novo produto para o mercado. Segundo o prefeito do Município de Fortaleza, o gás gerado no aterro sanitário poderá ser utilizado na frota de ônibus urbano do município. Com a usina de biogás, estima-se que a emissão de 500 mil toneladas de gás carbônico na atmosfera poderá ser evitada, o que significa melhoria na qualidade do ar. Diante da situação de grandes lucros viu-se que a população do entorno se torna invisível na participação desses lucros caracterizando conflitos socioeconômicos, onde os mais ricos tonam-se cada vez mais ricos e os mais pobres cada vez mais pobres (Diário do Nordeste, 2019).

Diante do entrevistado, pode ser percebido que há uma grande concentração de lucro por parte dos empreendimentos, e enquanto isso a população do entorno vive ameaçada de diversos riscos, desde os riscos econômicos, sociais aos ricos ambientais, de saúde, dentre outros (Egler, 2005; Thouret; Veyret, 2007; Acselrad et al., 2008).

Para Acselrad, et al. (2009), existe uma divisão socioespacial da degradação ambiental legitimada para os mais pobres carregarem o fardo ambiental. De modo que a situação de conforto dos mais ricos não permite enxergar os que estão às margens, aqui denominados população do entorno. Em Acselrad (2013), diz que o poder político dos capitalistas com os elevados ganhos dos capitais resulta em angariar apoio e trabalhadores para mais investimentos. Isso se confirma diante dos dados pesquisados no EIA/RIMA 
(Ecosam, 2011), onde durante a negociação para a realização do negócio, da implantação e operacionalização dos empreendimentos em discussão as taxas de lucros esperados já estão fixadas e ao mesmo tempo em que aumentam os lucros, aumenta a degradação ambiental. Outra situação observada é que os rejeitos por sua vez são descartados próximo aos mais pobres os que residem às margens do ASMOC, a população do entorno, afinal, nenhum dos empreendedores moram na localidade próxima do aterro sanitário.

\section{Atores sociais: Gerência de operacionalização do Aterro Sanitário ASMOC}

Mediante os questionários aplicados e realização de entrevista à gerência e analistas de operações do ASMOC para se obter informações sobre o aterro sanitário, obteve-se os seguintes resultados.

Quando questionado sobre o que existia no local onde foi instalado o aterro sanitário ASMOC, ele dissera que se tratava de um loteamento que foi desapropriado pelo Governo do Estado do Ceará, na década de 1980 e posteriormente na década de 1990 foi entregue à Ecofor Ambiental S/A para gerenciar o aterro e a Superintendência Estadual do Meio Ambiente (SEMACE) é quem vistoria a operação do Aterro. No que se refere à documentação para o licenciamento, a Ecofor assumiu a operação por meio da licença de operação emitida pela Superintendência Estadual do Meio Ambiente do Ceará (SEMACE), órgão ambiental estadual responsável, possui o alvará de funcionamento municipal e o Cadastro Federal do Instituto Brasileiro do Meio Ambiente e dos Recursos Naturais Renováveis (IBAMA). Sabe-se que o que se tem como conflito socioambiental é o fato da lagoa de chorume do ASMOC I está localizada a menos de $104 \mathrm{~m}$ da Lagoa João Batista e a $460 \mathrm{~m}$ do Riacho Garoto, o que pode comprometer a saúde da população do entorno e ainda, apresentar riscos de contaminação das águas e do solo.

Ao ser questionado sobre o quantitativo de funcionários feminino ou masculino destinado ao funcionamento do aterro e o grau de escolaridade, informou-se que o aterro ASMOC iniciou suas atividades com 30 empregados e com o decorrer dos anos passou a contar com um efetivo de 116. No que se refere à escolaridade, cincofuncionários possuem nível superior onde três destes são mulheres, quatro com nível técnico sendo um mulher e 107 na sua maioria obtiveram o nível fundamental completo sendo deste quantitativo três são mulheres. A partir desses resultados, pode-se perceber que o quadro de funcionários do gênero feminino é muito pequeno com relação aos homens.

Em se tratando da distância das residências do entorno do aterro sanitário, obtevese a informação de que existe nesse entorno aproximadamente 40 residências e que a residência mais próxima do aterro é de um raio de $10 \mathrm{~m}$. Nesse aspecto é possível perceber que pode haver diversos conflitos socioambientais, a exemplo de contaminação e poluição e riscos à saúde desses moradores do entorno, assim como, de acordo com Ministério Público Ambiental do Estado da Bahia, essa aproximação residencial de $10 \mathrm{~m}$ vem descumprir o estabelecido no relatório ambiental deste mesmo ministério que estipula uma distância média de no mínimo 2 km (MPBA, 2007).

De acordo com o informado pelo funcionário do aterro o ASMOC no que se refere ao apoio dado à população do entorno do aterro, este informa que tem desenvolvido várias ações de apoiado a população do entorno por gerar 80 empregos nessas comunidades; instalação e desenvolvimento de viveiro comunitário com treinamento semanal realizado por engenheiro agrônomo; Fornecimento de insumos para os eventos do calendário social da escola de ensino fundamental mais próxima das comunidades; Recuperação de vias de acesso às comunidades; Cursos profissionalizantes; Fornecimento de cestas básicas e Aulas de educação ambiental. Todo acesso da gestão do aterro com a comunidade do entorno é feito por meio das lideranças das comunidades. Diante do respondido, pode-se perceber que de acordo com a visita in loco não é feita uma assistência permanente na escola citada assim como na distribuição de cestas básicas à comunidade, mas apenas eventual. Também se viu como apresentado na figura que 
mostra a via de transporte que o acesso da comunidade ao aterro a única via de transporte deixa a desejar por ser muito estreita e não ter acesso adequado aos pedestres e ciclistas, tornando-se um risco trafegar no local.

Ao ser questionado sobre os impactos positivos e negativos antes e depois da implantação do aterro sanitário, foi citado que com a chegada do aterro vieram a geração de emprego e renda, o acesso à rede de água e energia elétrica e a construção de estradas que impactavam de forma positiva. Embora, diante da realidade observada in loco, apenas uma rua, a que dá acesso ao aterro ASMOC é asfaltada. As demais ruas não têm pavimentação, o que no período chuvoso tornam-se intransitáveis, causando muito desconforto à população. Dessa forma, quem mais se beneficia dos recursos naturais são empreendedores do aterro e da usina. A população do entorno é quem sofre com as problemáticas sociais e ambientais com a instalação e operacionalização dos referidos empreendimentos. Como analisado no RIMA (ECOFOR, 2011), o impacto ambiental e social por inexistência da pavimentação e pelo tráfego de caminhões pesados são citados como impacto negativo, embora até então, mesmo depois de oito anos do RIMA do ASMOC II e mais de 23 anos da operacionalização do ASMOC I, nada foi resolvido.

Quando perguntado sobre o tipo de certificação na área da qualidade, meio ambiente ou segurança do trabalho informou-se a operação do ASMOC possui certificação ISO 9000, ou seja, esta certificação atesta o padrão de qualidade da empresa e que tem validade de três anos e, após este período passará por uma nova auditoria de certificação. No que se refere à segurança do trabalho o ASMOC possui um departamento de segurança e medicina do trabalho, que fornece treinamento e acompanhamento constante a todos os trabalhadores, bem como o fornecimento de Equipamentos de Proteção Individual (EPI's) específicos para cada função desempenhada dentro da unidade. E que para atender à prevenção da poluição e a proteção ambiental a Ecofor cumpre todas as exigências constantes nos condicionantes de sua licença de operação, com a finalidade de garantir a prevenção do meio ambiente.

Perguntou-se se existia rio, lagoa ou riacho no entorno do aterro sanitário e se a empresa já havia recebido alguma autuação e obteve-se a resposta que tem o Riacho Garoto a 350 mde distância e que em 2011 o aterro foi autuado pela Superintendência Estadual do Meio Ambiente do Ceará (SEMACE), por atraso na entrega de monitoramento ambiental. Diante dessa situação, pode ser evidenciado de que o órgão ambiental responsável por fiscalizar e outorgar a renovação da licença ambiental, poderia ser mais rigoroso exigindo reparação dos impactos causados aos meios social e ambiental.

Ao ser indagado sobre a existência de um Estudo de Impacto Ambiental (EIA)e o Relatório de Impacto Ambiental (RIMA), o funcionário relatou que a ECOFOR não disponha a documentação do processo de implantação do ASMOC, ocorrido no final da década de 1980. Ou seja, há fragilidade nas informações no que se refere ao acesso ao conhecimento do referido equipamento.

Questionado sobre o monitoramento das águas, solo e ar e em qual período acontece, a resposta foi de que é realizado o monitoramento quadrimestralmente em conformidade da Licença de Operação (LO) e que são coletadas e analisadas as águas de seis poços de monitoramento, bem como as águas do riacho mais próximo, assim como existe implantação de sistema de drenagem de águas pluviais e de barreira vegetale existe plantio de vegetação nos taludes e prevenção de assoreamento. Também foi informado de que o aterro possui cinturão verde em todo o seu perímetro. E que há implantação do sistema de coleta e armazenamento de percolados com tratamento em ETE.

No intuito de conhecer melhor a população do entorno foi indagado se a gestão do aterro já havia aplicado questionários junto à população circunvizinha ou do entorno com a finalidade de avaliar a incidência ou não de doenças relacionadas com a disposição de resíduos sólidos, como por exemplo, dengue, leptospirose, toxoplasmose, câncer, bem como, a realização de levantamento da ocorrência de doenças causadas por vetores, assim

Rev. Bras. Gest. Amb. Sustent., 2021, vol. 8, n. 20, p. 1707-1734. 
como doenças respiratórias asma, bronquite e até mesmo câncer no sistema respiratório e as resposta foram de que nunca foi feito coisa do tipo.

No que diz respeito ao meio biótico, ao questionar o funcionário do aterro do ASMOC, se havia ou não plantio de mudas que sejam atrativas aos animais (frutíferas) em áreas apropriadas e se há ou não compensação ambiental com reflorestamento de área de com espécies nativas, ainda, se há implantação da cortina vegetal, o funcionário respondeu que não havia plantio desse tipo de mudas, nem reflorestamento e nem tão pouco implantação de cortina vegetal.

Ao ser questionado sobre se haveria ou não a possibilidade de saber a quantidade de gases de efeito estufa é emitido na atmosfera advindo do aterro sanitário do ASMOC, a resposta foi de que a produção de biogás em aterro sanitário está relacionada a uma série de fatores operacionais e de clima, incluindo a caracterização dos resíduos destinados e queo ASMOC não fazia essa estimativa com base na quantidade de resíduos destinados.

Foi indagado para a gestão do ASMOC o que mudou no aterro sanitário do ASMOC após a instalação da usina GNR Fortaleza Valorização de Biogás Ltda e obteve-se a seguinte resposta: Todo o biogás produzido pelo aterro, que antes era apenas queimado em "flares" conectados aos drenos verticais, com a finalidade de transformar o gás metano em $\mathrm{CO}_{2}$, passou a ser captado e purificado da planta da GNR Fortaleza.

Ao tratar sobre se havia ou não desvalorização das moradias no entorno do aterro sanitário do ASMOC, o funcionário respondeu que não era do seu conhecimento tal desvalorização. 0 que se sabe de acordo com que se afirma o próprio Estudo de Impacto Ambiental (EIA) (ECOSAM, 2011, p. 281), que há uma grande desvalorização do valor de venda dos imóveis no entorno de aterro sanitário.

Perguntou-se também se houve ou não negociação com a população do entorno para a instalação do novo aterro sanitário do ASMOC, a resposta foi que para a implantação do novo aterro sanitário houve uma audiência pública ocorrida na escola mais próxima ao aterro, além de diversas visitas do órgão ambiental licenciador às localidades mais próximas. 0 que contraria a resposta de vários moradores do entorno no ato da entrevista, ao afirmarem de não ter sido consultados sobre a instalação dos equipamentos em discussão.

Diante do questionado sobre se haveria ou não algum benefício oferecido a população do entorno pelo fato da instalação do novo aterro sanitário do ASMOC, respondeu-se que com a implantação do novo aterro, todos os benefícios já em curso em relação ao ASMOC foram mantidos, tais como a geração de emprego, construção de estradas de acesso, rede de energia elétrica e de água, aquisição e doação de terreno para ampliação da escola mais próxima, ações relacionadas ao calendário social com entrega de cestas básicas e demais itens de uso familiar (Páscoa, dia das mães, dia da mulher, dia da criança, dia do professor e no natal). 0 que boa parte dessas ações não se confirma por parte dos moradores do entorno, que a perguntar sobre a relação com os atores sociais do aterro e da usina, foi relatado de que não tinham aproximação, não conheciam essas pessoas. Diante dessa situação exposta pela população do entorno, evidencia-se certo distanciamento entre os atores dos empreendimentos e a comunidade do entorno.

Ao perguntar sobre a participação ou não da população do entorno na decisão da instalação da usina de biogás GNR Fortaleza, a resposta foi de que não foi necessário, "uma vez que o empreendimento só proporciona benefícios a sociedade e ao meio ambiente". Embora, sabe-se que de acordo com o discutido no decorrer desse estudo, a usina provoca muitos ruídos e que isso seria suficiente para uma consulta à comunidade do entorno do aterro. Assim sendo, diante da resposta de que não se faz necessário participação da comunidade do entorno, torna visível a falta de comunicação com a comunidade do entorno, o que cada vez mais pode promover a desigualdade social, o descumprimento da inclusão social tão evidenciada na Política Nacional dos Resíduos Sólidos. Dessa forma, a 
população do entorno torna-se cada vez mais sem vez e sem voz e entendida somente como mais um na periferia do aterro sanitário e da usina.

No questionamento feito sobre a relação entre o meio ambiente e a população do entorno do aterro sanitário do ASMOC, a usina de biogás GNR Fortaleza e o ASMOC, respondeu que a relação é a melhor possível, com interação e visitas constantes da equipe do Aterro à comunidade, bem como acesso direto das lideranças da comunidade com a gestão do aterro. 0 que não se confirma na entrevista da maioria dos moradores por entenderem que poderiam ser melhores assistidos nas suas necessidades físicas, psíquicas e de comportamento.

Ao indagar sobre a instalação e operacionalização do aterro sanitário do ASMOC, a gerência de operacionalização do aterro ASMOC, José Cordeiro Moreira, dissera que o ASMOC veio para dar destinação ambientalmente adequada aos resíduos sólidos urbanos de Fortaleza, embora, ainda é um grande desafio realizar a coleta seletiva dos resíduos, assim como promover a reciclagem desses resíduos tendo em vista aumentar a vida útil do aterro sanitário. A cada ano vê-se aumentar a produção dos resíduos sólidos urbanos assim como cresce o número de habitantes e por isso precisa-se planejar políticas públicas que torne a cidade mais sustentável.

Portanto, diante do pesquisado percebe-se que falta a efetividade das políticas públicas ambientais a exemplo da Política Nacional do Meio Ambiente (Brasil, 1981), da Política Nacional de Educação Ambiental que, por meio da Lei no 9.795/1999 (Brasil, 1999), ao tratar no seu art. $2^{\circ}$ da Educação Ambiental como componente essencial e permanente de "forma articulada em todos os níveis e modalidades do processo educativo, em caráter formal e não-formal", assim como a Política Nacional dos Resíduos Sólidos (Brasil, 2010), através da Lei no 12.305/2010 ao tratar da gestão dos resíduos sólidos de forma compartilhada e com prazos para sua atuação a exemplo da erradicação dos lixões em 2014 prorrogado para 2018, instalação de aterro sanitário de forma consorciada, dentre outras políticas públicas. Também vale destacar da importante contribuição da Ecologia Política que permite visualizar os conflitos socioambientais e econômicos existentes na relação da população com os equipamentos em discussão.

\section{Considerações finais}

A geração do biometano através do aterro e da usina de biogás contribui diretamente para a substituição de combustíveis fósseis usados em indústrias, residências, comércios e veículos automotores. 0 modelo de geração de biogás da usina GNR sinaliza que pode ser replicado para outros municípios brasileiros desde que obedeça à legislação ambiental vigente. Embora, diversas externalidades negativas foram geradas com a instalação e operacionalização do aterro sanitário e a usina de biogás.

Nesse sentido, os impactos ambientais negativos na área de estudo potencializaram a deflagração de alguns conflitos socioambientais com a população do entorno. Como pôde ser percebido no decorrer desta pesquisa, diversos são os conflitos socioambientais decorrentes da instalação e operacionalização do aterro sanitário do ASMOC e da Usina de biogás GNR Fortaleza e a população do entorno, desde a geração de impactos ambientais diversos em corpos hídricos que comprometem a saúde da população local, até a desapropriação de algumas áreas e a expulsão de alguns atores sociais da comunidade que tiveram seus territórios invadidos através de uma relação desigual de poder.

Dessa forma, pôde ser percebido através das visitas in loco e mediante as falas da população do entorno, que as relações de poder são desiguais entre os atores sociais.Além disso, pessoas da comunidade do entorno do empreendimento não apresentaram consciência da dimensão dos riscos e conflitos socioambientais que vivem e 
consequentemente as gerações futuras terão. Isso é muito preocupante, pois gera uma situação de injustiça ambiental local.

Verificou-se também, que muitas vezes falta o direito básico para a sobrevivência da população do entorno, a exemplo de alimentação, condições de saúde e formação educacional. A educação ambiental deve ser inserida no contexto da comunidade de forma integral buscando a resolução de conflitos socioambientais. Faz-se necessário um diálogo permanente e contínuo entre os gestores dos dois empreendimentos e a população do entorno que sofre as injustiças ambientais causadas pela exposição às externalidades negativas.

Portanto, percebe-se insuficiência na gestão e execução das políticas públicas.

\section{Conflitos de interesse}

Os autores declaram não haver conflitos de interesse.

\section{Referências}

Acselrad, H. Ambientação das lutas sociais: o caso do movimento por justiça ambiental. Estudos Avançados, v. 24, n. 68, p. 103-119, 2010. https://doi.org/10.1590/S010340142010000100010

Acselrad, H. Desigualdade ambiental, econômica e política. Astrolabio, n. 11, p. 105-123, 2013.

Acselrad, H.; Mello, C. Y.; Bezerra, G. N. O Que é Justiça Ambiental. Rio de Janeiro: Garamond, 2009.

Almeida, J. R. N. Desigualdades brasileiras: aspectos econômicos históricos. In: Pádua, J. A. Desenvolvimento, justiça e meio ambiente. São Paulo: Petrópolis, 2009.

Araújo, G.; Gomes, E. A contribuição da Ecologia Política e do Sustainable Livelihoods Approach nos estudos ambientais no meio rural do Brasil: um olhar sobre os reassentados de Petrolândia. GEOgraphia, v.19, n. 40, p. 123-137, 2017.

Biernack, P.; Waldorf, D. Snowball sampling: Problems and techniques of chain referral sampling. Sociological Methods and Research, v. 10, n. 2, p. 141-163, 1981. https://doi.org/10.1177/004912418101000205

Bordalo, C. A. L. Os conflitos socioambientais pelo uso da água no Brasil na perspectiva da Ecologia Política. Revista de Geografia e Ecologia Política - AMBIENTES, v. 1, n. 3, p. 78-110, 2019.

Brasil. Lei no 6.938, de 31 de agosto de 1981. Dispõe sobre a Política Nacional do Meio Ambiente, seus fins e mecanismos de formulação e aplicação, e dá outras providências. Disponível em: <https://www2.camara.leg.br/legin/fed/lei/1980-1987/lei-6938-31agosto-1981-366135-publicacaooriginal-1-pl.html>. Acesso em: 18 jun. 2019.

Brasil. Lei no 9.795, de 27 de abril de 1999. Dispõe sobre a educação ambiental, institui a Política Nacional de Educação Ambiental e dá outras providências. Disponível em: <http://www.planalto.gov.br/ccivil_03/leis/19795.htm>. Acesso em: 18 jun. 2016.

Brasil. Resolução CONAMA no 357, de 17 de março de 2005. Dispõe sobre a classificação dos corpos de água e diretrizes ambientais para o seu enquadramento, bem como estabelece as condições e padrões de lançamento de efluentes, e dá outras providências. Disponível em: <http://pnqa.ana.gov.br/Publicacao/RESOLUCAO_CONAMA_ n_357.pdf>. Acesso em: 18 jun. 2020. 
Brasil. Resolução CONAMA no 404, de 11 de novembro de 2008. Estabelece critérios e diretrizes para o licenciamento ambiental de aterro sanitário de pequeno porte de resíduos sólidos urbanos. Disponível em: <http://www.mp.go.gov.br/portalweb/ $\mathrm{hp} / 9 /$ docs/res_conama_404_-_estabelece_criterios_e_diretrizes_para_o.pdf $>$. Acesso em: 18 jun. 2020.

Brasil. Lei no 12.305, de 02 de agosto de 2010. Institui a Política Nacional de Resíduos Sólidos; altera a Lei no 9.605, de 12 de fevereiro de 1998; e dá outras providências. Disponível em: <http://www.planalto.gov.br/ccivil_03/_ato2007-2010/2010/lei/ 112305.htm>. Acesso em: 02 ago. 2020.

Brasil. Resolução CONAMA no 430, de 13 de maio de 2011. Dispõe sobre as condições e padrões de lançamento de efluentes, complementa e altera a Resolução no 357, de 17 de março de 2005, do Conselho Nacional do Meio Ambiente-CONAMA. Disponível em: <https://www.legisweb.com.br/legislacao/?id=114770 >. Acesso em: 18 jun. 2020.

Brito, I. A. Estudo de caso do aterro sanitário da Caximba. Curitiba: Universidade Federal do Paraná, 2005. (Monografia de graduação).

Carvalho, M. L. F. Políticas de gestão dos resíduos sólidos domiciliares na Cidade de Fortaleza-Ceará: avanços e desafios. João Pessoa: Universidade Federal da Paraíba, 2016. (Dissertação de mestrado).

CEAMA - Centro de Apoio às Promotorias de Meio Ambiente e Urbanismo. Parecer Técnico do CEAMA. Salvador: MPBA, 2007. Disponível em: <http://www.mp.ba.gov.br/atuacao/ceama/programas/laudos/santo/cruz_almas_desafio _lixo_2007.pdf>. Acesso em: 25 maio 2019.

CETESB - Companhia Ambiental do Estado de São Paulo. Termelétrica do Aterro Bandeirantes reduz emissão de $\mathrm{CO}_{2}$ para a atmosfera. 2004. Disponível em: <https://cetesb.sp.gov.br/biogas/2004/03/25/termeletrica-do-aterro-bandeirantesreduz-emissao-de-co2-para-atmosfera>. Acesso em: 20 jan. 2020.

Conferência de Tbilisi. Recomendações da Conferência Intergovernamental sobre Educação Ambiental aos Países Membros. Tbilisi: CEI, 1977. Disponível em: <https://www.mma.gov.br/informma/item/8065-recomenda\%C3\%A7\%C3\%B5es-detbilisi.html>. Acesso em: 15 maio 2020.

Diário do Nordeste. Usina de biometano já planeja ampliar produção em 2019. Disponível em: <https://diariodonordeste.verdesmares.com.br/editorias/negocios/usina-debiometano-ja-planeja-ampliar-producao-em-2019-1.1924919>. Acesso em: 06 out. 2019.

Diário do Nordeste. A energia que vem do lixo descartado e gera riqueza. 2018. Disponível em: <https://www.diariodepernambuco.com.br/noticia/economia/2018/09/a-energiaque-vem-do-lixo-descartado-e-gera-riqueza.html>. Acesso em: 06 out. 2019.

Dias, G. F. Educação ambiental: princípios e práticas. São Paulo, Gaia, 1992.

ECOFORA S/A. Relatório de Impacto Ambiental (RIMA): projeto de implantação para a ampliação do Aterro Sanitário Metropolitano de Caucaia-CE. Fortaleza: ECOFOR, 2011. Disponível em: <https://www.semace.ce.gov.br/wp-content/uploads/sites/46/2020/06/ 11512641_4_RIMA-ASMOC-VERSAO-FINAL.pdf>. Acesso em: 31 mar. 2021.

ECOSAM - Consultoria em Saneamento Ambiental Ltda. Aterro Sanitário Metropolitano de Caucaia-CE: Ampliação. Estudo de Impacto Ambiental (EIA). Relatório de Impacto Ambiental. Fortaleza: ECOSAM, 2011. 
Egler, C. A. Risco ambiental como critério de gestão do território: uma aplicação à Zona Costeira Brasileira. Brasília. O Autor, 2005. (Mimeografado).

Ferreira, S. M. I. L.; Penteado. M. S.; Silva Júnior, M. F. Território e territorialidade no contexto hospitalar: uma abordagem interdisciplinar. Saúde e Sociedade, v. 22, n. 3, p. 804-814, 2013.

Fortaleza. Plano Municipal de Gestão Integrada de Resíduos Sólidos Urbanos (PMGIRS). Fortaleza: Município de Fortaleza, 2012.

Forum de Perus. Vereador mais votado em Perus é questionado sobre o Bairro. 2009. Disponível em: <http://newperus.blogspot.com/2009/02/vereador-mais-votado-emperus-e.html>.Acesso em: 20 jan. 2020.

Giddens, A. As consequências da modernidade. São Paulo: EDUSP, 1991.

Gouveia, N.; Prado, R. R. Riscos à saúde em áreas próximas a aterros de resíduos sólidos urbanos. Revista de Saúde Pública, v. 44, $\begin{array}{lllll} & \text { n. 5, } & \text { p. } 859 & 2010 .\end{array}$ https://doi.org/10.1590/S0034-89102010005000029

Guedes, M. J. F.; Almeida, M. V. A.; Curi, R. C. Análise da evolução de conflito ambiental em um aterro sanitário na Paraíba, Brasil. Revista Ibero-Americana de Ciências

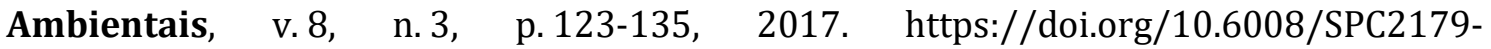
6858.2017.003.0012

Guedes, M. J. F.; Ribeiro, M. M. R. Aplicação de metodologias de análise de conflito ambiental ao aterro sanitário de Puxinanã (PB). Engenharia Sanitária e Ambiental, v. 22, n. 1, p. 81-93, 2017. https://doi.org/10.1590/S1413-41522016147878

Kalecki, M. Aspectos políticos do Pleno Emprego. In: Migilioli, J. (Comp.). Crescimento e ciclo nas economias capitalistas. 2. ed. São Paulo: Hucitec, 1987.

Leff, E. Racionalidade ambiental: a reapropriação social da natureza. Rio de Janeiro: Civilização Brasileira, 2006.

Little, P. E. Territórios sociais e povos tradicionais no Brasil: por uma Antropologia da territorialidade. Brasília: DAN/UnB, 2002. (Série Antropologia, 322).

Little, P. E. Ecologia Política como etnografia: um guia teórico e metodológico. Revista Horizontes Antropológicos, v. 12, n. 25, p. 85-103, 2006. https://doi.org/10.1590/ S0104-71832006000100005

Mapa da Injustiça Ambiental e Saúde no Brasil. Resumo. Disponível em: <http://mapadeconflitos.ensp.fiocruz.br>. Acesso em: 12 fev. 2020.

Martinez-Alier, J. O ecologismo dos pobres: conflitos ambientais e linguagens de valoração. São Paulo: Contexto, 2007.

Martinez-Alier, J. The Economist: Let them eat pollution. Barcelona: Icaria, 1992.

Minayo, M. C. Ciência, técnica e arte: o desafio da Pesquisa Social. In: Minayo, M. C. (Org.). Pesquisa social: teoria, método e criatividade. Petrópolis: Vozes, 2001.

MPBA - Ministério Público do Estado da Bahia. Desafio do lixo: problemas, responsabilidades e perspectivas: Relatório 2006/2007. Salvador: Ministério Público da Bahia, Centro de Apoio Operacional às Promotorias de Justiça de Meio Ambiente, 2007. Disponível em: <http://www.mp.go.gov.br/portalweb/hp/9/docs/rsudoutrina_18.pdf>. Acesso em: 18 ago. 2020.

Muniz, L. M. Ecologia Política: o campo de estudo dos conflitos socioambientais. Revista Pós Ciências Sociais, v. 6, n. 12, p. 193, 2009. 
Pelicioni, M. C. F. Educação ambiental, qualidade de vida e sustentabilidade. Saúde \& Sociedade, v. 7, p. 19-31, 1998.

Porto, M. F. S.; Martinez-Alier, J. Ecologia política, economia ecológica e saúde coletiva: interfaces para a sustentabilidade do desenvolvimento e para a promoção da saúde. Cadernos de Saúde Pública, v. 23, $\quad$ n. 4, p.S503-S512, 2007. https://doi.org/10.1590/S0102-311X2007001600011

Quintas, J. S. Educação no processo de gestão ambiental: uma proposta de educação ambiental transformadora e emancipatória. In: Layrargues, P. P. (Coord.). Identidades da educação ambiental brasileira. Brasília: Ministério do Meio Ambiente, 2004. p. 113-138.

Raffestin, C. Por uma geografia do poder. São Paulo: Ática, 1993.

Scotto, G. Conflitos ambientais no Brasil: natureza para todos ou somente para alguns? Rio de Janeiro: IBASE, 1997.

SEBIGASCOTICA. Biogás e biometano ganham espaço em SP. São Paulo: SEBIGAS, 2017. Disponível em: <http://sebigascotica.com.br/noticias/biogas-em-sao-paulo-biometanoem-sp.html>. Acesso em: 22 set. 2019.

Souza. S. S.; Teixeira, G. F. Aterro sanitário: um problema de Cruz das Almas. Revista NAU Social, v. 3, n. 4, p. 29-37, 2012. https://doi.org/10.9771/ns.v3i4.31176

SUDEMA - Superintendência de Administração do Meio Ambiente. Parecer técnico da comissão de EIA/Rima. João Pessoa: SUDEMA, 2011.

Thouret, J. C. Os riscos nos países em desenvolvimento. In: Veyret, Y. (Org.). Os riscos: o homem como agressor e vítima do meio ambiente. São Paulo: Contexto, 2007. p. 83-85.

Tuan, Y.-F. Paisagens do medo. São Paulo: UNESP, 2005.

Veyret, Y. (Org.). Os riscos: o homem como agressor e vítima do meio ambiente. São Paulo: Contexto, 2007.

WHO - World Health Organization. Methods of assessing risk to health from exposure to hazards released from wastelandfills. Poland: WHO, 2000.

Zimmerer, K. S.; Bassett, T. J. Approaching political ecology: Society, nature, and scale in human-environment studies. In: Zimmerer, K. S.; Basset, T. J. (Eds.). Political Ecology: An integrative approach to geography and environment-development studies. New York: The Guilford Press, 2003.

Informação da Licença: Este é um artigo Open Access distribuído sob os termos da Licença Creative Commons Attribution, que permite uso irrestrito, distribuição e reprodução em qualquer meio, desde que a obra original seja devidamente citada. 